\title{
Growth Factors and Alcohol Use Disorder
}

\author{
Mirit Liran, ${ }^{1}$ Nofar Rahamim, ${ }^{2}$ Dorit Ron, ${ }^{3}$ and Segev Barak ${ }^{1,2,4}$ \\ ${ }^{1}$ Department of Neurobiology, ${ }^{2}$ Sagol School of Neuroscience, Tel Aviv University, 69978 Tel Aviv, Israel \\ ${ }^{3}$ Department of Neurology, University of California, 675 Nelson Rising Lane, San Francisco, \\ California 94143-0663, USA \\ ${ }^{4}$ School of Psychological Sciences, Tel Aviv University, 69978 Tel Aviv, Israel \\ Correspondence: barakseg@tau.ac.il
}

Neurotrophic growth factors were originally characterized for their support in neuronal differentiation, outgrowth, and survival during development. However, it has been acknowledged that they also play a vital role in the adult brain. Abnormalities in growth factors have been implicated in a variety of neurological and psychiatric disorders, including alcohol use disorder (AUD). This work focuses on the interaction between alcohol and growth factors. We review literature suggesting that several growth factors play a unique role in the regulation of alcohol consumption, and that breakdown in these growth factor systems is linked to the development of AUD. Specifically, we focus on the brain-derived neurotrophic factor (BDNF), glial cell line-derived neurotrophic factor (GDNF), fibroblast growth factor 2 (FGF2), and insulin growth factor 1 (IGF-1). We also review the literature on the potential role of midkine (MDK) and pleiotrophin (PTN) and their receptor, anaplastic lymphoma kinase (ALK), in AUD. We show that alcohol alters the expression of these growth factors or their receptors in brain regions previously implicated in addiction, and that manipulations on these growth factors and their downstream signaling can affect alcohol-drinking behaviors in animal models. We conclude that there is a need for translational and clinical research to assess the therapeutic potential of new pharmacotherapies targeting these systems.

\begin{abstract}
$A^{\text {lcohol use disorder (AUD) is a worldwide }}$ Aproblem, characterized by increased alcohol consumption over time, persistent alcohol use despite adverse consequences, and loss of control over alcohol drinking. AUD affects approximately $10 \%-15 \%$ of the population worldwide (World Health Organization 2018; Carvalho et al. 2019) and causes significant health, societal, and economic burdens (McGinnis and Foege 1999; Rehm 2011; Whiteford et al. 2013). Thus, determining the neuroadaptations
\end{abstract}

that control the escalation from moderate-tocompulsive alcohol intake is of great interest to alleviate the societal burden of AUD. Curiously however, although alcohol is widely consumed worldwide, only a minority of the population consume large quantities of alcohol, and an even smaller portion of alcohol users develop a full-blown alcoholism (World Health Organization 2014; Grant et al. 2017). This suggests the existence of innate and/or acquired mechanisms that protect against the transition from

Editors: R. Christopher Pierce, Ellen M. Unterwald, and Paul J. Kenny

Additional Perspectives on Addiction available at www.perspectivesinmedicine.org

Copyright (C) 2020 Cold Spring Harbor Laboratory Press; all rights reserved; doi: 10.1101/cshperspect.a039271

Cite this article as Cold Spring Harb Perspect Med 2020;10:a039271 
M. Liran et al.

moderate-to-excessive, uncontrolled, and compulsive alcohol use.

Here, we review studies suggesting that several growth factors are implicated in the endogenous pathways that control the transition from moderate-to-excessive alcohol consumption. Specifically, we focus on brain-derived neurotrophic factor (BDNF), glial cell line-derived neurotrophic factor (GDNF), fibroblast growth factor 2 (FGF2), insulin growth factor 1 (IGF-1), and on anaplastic lymphoma kinase (ALK) and the growth factors that bind to this receptor tyrosine kinase-midkine (MDK) and pleiotrophin (PTN).

Growth factors, originally discovered for their ability to support neuronal development, survival, and differentiation (e.g., Davies et al. 1986; Lin et al. 1993; Ford-Perriss et al. 2001; Muramatsu 2011; Werner and LeRoith 2014), perform a variety of functions in the adult brain, including regulation of neuronal plasticity, learning, and memory (Molteni et al. 2001b; Park and Poo 2013; Zagrebelsky and Korte 2014). Substance use disorders have been characterized as diseases of maladaptive plasticity (Lüscher and Malenka 2011; Feltenstein and See 2013; Nestler 2013) and, thus, alterations in the growth factor systems present putative molecular mediators of the long-lasting effects of drugs of abuse, including alcohol (Alguacil and Herradón 2015; Logrip et al. 2015; Ron and Barak 2016; Barak et al. 2019; Even-Chen and Barak 2019a). In addition, as detailed below, several studies have identified alterations in certain growth factors in the plasma or in the postmortem brains of human AUD patients, further suggesting that growth factors are extremely relevant targets to investigate, and that molecules that can interact with growth factors, their receptors or downstream pathways may provide strong therapeutic candidates.

As detailed below, in most cases, the anatomical focus for the addiction-related action of growth factors is centered in two main brain circuitries, which have been implicated in addiction: the "mesocorticolimbic system," composed of dopaminergic projections from the ventral tegmental area (VTA) to limbic regions (e.g., the nucleus accumbens [NAc], amyg- dala, hippocampus) and to the prefrontal cortex (PFC) (Koob and Le Moal 2001; Volkow and Morales 2015), and the "nigrostriatal system," composed of dopaminergic projections, form the substantia nigra (SN) to the dorsal striatum (Wise 2009; Everitt and Robbins 2013). Regions comprising these brain circuitries further interact with each other and additional brain regions (Ron and Barak 2016; Abrahao et al. 2017), and, as we discuss below, neuroadaptations in these circuitries may lead to addiction phenotypes.

\section{BDNF}

BDNF is a member of the nerve growth factor (NGF) family of neurotrophic factors (Barde et al. 1982; Barde 1994). BDNF signals by binding to tropomyosin-related kinase B (TrkB), a receptor tyrosine kinase that autophosphorylates upon binding to BDNF, initiating downstream signaling via the mitogen-activated protein kinase/extracellular signal-regulated kinase (MAPK/ERK), phospholipase C $\gamma$ (PLC $\gamma$ ), and phosphoinositol 3-kinase (PI3K) pathways (Huang and Reichardt 2003). Both BDNF and TrkB are widely expressed throughout the brain, and particularly in the cortex, hippocampus, and cerebellum (Hofer et al. 1990; Klein et al. 1990). BDNF regulates a variety of neuronal processes, including neuronal development and survival, synaptic plasticity, and learning and memory processes (Castrén 2004; Lu et al. 2008, 2014; Minichiello 2009; Cowansage et al. 2010). In contrast, dysregulation of BDNF function has been implicated in multiple neuropsychiatric disorders (Autry and Monteggia 2012; Castrén 2014), including depression (Koo et al. 2019), schizophrenia (Buckley et al. 2007), and anxiety disorders (Andero et al. 2014), as well as drug abuse (Ghitza et al. 2010; Logrip et al. 2015; Koskela et al. 2017).

BDNF in the mesolimbic dopamine system promotes drug sensitization and self-administration, particularly for cocaine (Horger et al. 1999; Lu et al. 2004; Graham et al. 2007, 2009) but also for opiates (Vargas-Perez et al. 2009; Wan et al. 2011). In contrast, elevating BDNF levels in the medial prefrontal cortex (mPFC) can reverse molecular adaptations 
underlying stimulant drug-seeking (Berglind et al. 2007, 2009; Hearing et al. 2008; SadriVakili et al. 2010; Whitfield et al. 2011; Sun et al. 2013).

\section{Alcohol Regulation of BDNF Expression in the Brain}

$B d n f$ messenger RNA (mRNA) expression is elevated in the dorsal striatum in response to acute alcohol exposure, or moderate alcohol consumption (Logrip et al. 2015). Acute injection of alcohol $(2 \mathrm{~g} / \mathrm{kg})$ significantly increased $B d n f$ mRNA levels in the dorsal striatum of mice (McGough et al. 2004). Importantly, the increase in Bdnf mRNA in the dorsal striatum was observed in mice after 4 weeks of voluntary $10 \%$ alcohol consumption in an unlimited 2bottle choice (2-BC) access paradigm that generates moderate levels $(\sim 10 \mathrm{~g} / \mathrm{kg} / 24 \mathrm{~h})$ of alcohol intake (McGough et al. 2004). BDNF was also elevated after a single 4-h session of 2$\mathrm{BC}$ access (5.6 g/ $\mathrm{kg}$ intake) under a modified drinking in the dark (DID) paradigm (Logrip et al. 2009). A similar increase in Bdnf mRNA expression was observed in the dorsal striatum following rat operant alcohol self-administration of $10 \%$ alcohol, with substantially greater alcohol-induced $B d n f$ levels in the dorsolateral striatum (DLS), as compared to the dorsomedial striatum (DMS) (Jeanblanc et al. 2009). Interestingly, these increases in $B d n f$ expression were restricted to the dorsal striatum, with no similar effects in the NAc (McGough et al. 2004; Logrip et al. 2009). Moreover, sucrose consumption did not affect $B d n f$ expression in these brain regions (Logrip et al. 2009). Together these data demonstrate that acute alcohol exposure and chronic alcohol consumption at moderate levels (Dole and Gentry 1984) lead to increased striatal $B d n f$, which results in BDNF release and activation of TrkB-mediated ERK1/2 signaling (Logrip et al. 2008).

In contrast to the increases in dorsal striatal $B d n f$ mRNA observed following moderate alcohol intake, escalated alcohol drinking following 6 weeks of daily drinking (Rhodes et al. 2007), generated no alteration in $B d n f$ mRNA expression (Logrip et al. 2009). Moreover, long-term consumption of alcohol in the intermittent access to alcohol 2-BC (IA2BC) procedure in which rodents have concurrent access to one bottle containing 20\% alcohol and a second bottle containing water, led to increased membranal localization of the low-affinity BDNF receptor, p75 neurotrophin receptor (p75NTR) (Darcq et al. 2016), whose activities oppose those of the TrkB receptor (Kraemer et al. 2014). In addition, long-term excessive alcohol use led to a reduction in the mRNA expression of the growth factor in cortical regions (Logrip et al. 2009), including the mPFC of mice (Darcq et al. 2015) and rats (Tapocik et al. 2014). Relatedly, BDNF protein expression in the $\mathrm{mPFC}$ of alcohol-dependent mice was lower compared to nondependent mice (Haun et al. 2018). Taken together, as alcohol consumption can elevate $B d n f$ mRNA expression after 4 or more weeks of moderate drinking, the breakdown of alcohol's ability to up-regulate $B d n f$ expression following higher levels of alcohol intake suggests the possible loss of a protective mechanism.

Interestingly, analysis of the effects of chronic alcohol consumption on different exons of the $B d n f$ gene in the hippocampus showed that alcohol up-regulated the expression of exons II, III, VI IX, but down-regulated the expression of exon VIII, with no effects on exon I and IV expression (Stragier et al. 2015). These expression changes correlate with enrichment in acetylated $\mathrm{H} 3$ at $B d n f$ promoter PVI and trimethylated H3 at PII and PIII (Stragier et al. 2015).

Alcohol exposure in protocols of nonvoluntary alcohol exposure were also shown to affect BDNF expression. For example, a short withdrawal from vapor chambers resulted in increased $B d n f$ expression in the hippocampus and hypothalamamic supraoptic nucleus (Tapia-Arancibia et al. 2001). Likewise, the BDNF protein level was increased in the parietal cortex and septal nucleus in rats exposed to alcohol via a liquid diet (Miller 2004; Miller and Mooney 2004), and in the hippocampus, cingulate and motor cortex of rats were withdrawn from an alcohol liquid diet (Alele and Devaud 2013), which leads to very high, nonphysiological levels of alcohol intake. In contrast, $B d n f$ 
M. Liran et al.

mRNA was reduced in response to withdrawal from voluntary alcohol drinking in the 2-BC paradigm (Briones and Woods 2013). Finally, an acute injection of alcohol increased BDNF protein levels in the medial $(\mathrm{MeA})$ and central nuclei of the amygdala (CeA) (Pandey et al. 2008), whereas withdrawal in alcohol-dependent rats via liquid diet chronic alcohol exposure led to reduced amygdalar BDNF expression (You et al. 2014).

A possible mechanism for regulating mRNA expression involves microRNAs (miRs), short noncoding RNA sequences that inhibit the translation of mRNA by binding to cytoplasmic mRNA and targeting them for degradation (Bartel 2004). It has been shown that the down-regulation of $B d n f$ expression in the mPFC is associated with elevated levels of two miRs that specifically target $B d n f$ mRNA. Specifically, excessive alcohol consumption increased the expression of miR30a-5p in mice (Darcq et al. 2015), and protracted alcohol withdrawal in dependent rats resulted in increased expression of miR-206 (Tapocik et al. 2014). Importantly, the expression of these miRs negatively correlated with BDNF expression in both paradigms (Tapocik et al. 2014; Darcq et al. 2015). It is also possible that alcohol regulates BDNF in the striatum via altering the expression of other BDNF targeting miRs such as miR124a (Bahi and Dreyer 2013).

Innately lower BDNF expression may provide a predisposition factor in rats for higher alcohol consumption, as alcohol-preferring (P) rats, genetically selected for high alcohol intake and preference (Li et al. 1987), display reduced BDNF protein levels in the NAc (Yan et al. 2005) and the $\mathrm{CeA}$ and $\mathrm{MeA}$ and bed nucleus of the stria terminalis (BNST) (Prakash et al. 2008; Moonat et al. 2011) relative to the low-drinking nonpreferring (NP) rats. In summary, the surveyed data indicate that while acute or moderate alcohol exposure increases $B d n f$ expression in several brain regions, including the dorsal striatum, and particularly in the DLS, chronic alcohol reduces the expression of the growth factor in the cortex and hippocampus, and lower BDNF expression levels are associated with elevated alcohol consumption (see Table 1 for a summary of the effects of alcohol on brain BDNF expression.)

As BDNF's blood concentration was suggested to reflect the content of the growth factor in the brain (Karege et al. 2002; Klein et al. 2011), studies in humans have attempted to link the peripheral levels on BDNF with factors related to alcohol-drinking behaviors. For example, patients in the state of alcohol intoxication had increased plasma levels of BDNF (Chul et al. 2009; Heberlein et al. 2010). However, studies that examined BDNF levels in alcoholdependent patients at the time of hospitalization yielded mixed results. While Zanardini et al (2011) described lower BDNF serum levels in alcohol-dependent patients compared with healthy controls, other studies found no differences between the alcoholic patients and the control subjects (Huang et al. 2008; Heberlein et al. 2010; Costa et al. 2011). Monitoring the peripheral BDNF levels of patients diagnosed with AUD after 10 months of abstinence revealed lower plasma concentrations of BDNF, as compared with control group (García-Marchena et al. 2017). Similarly, a decreased plasma BDNF concentration was reported after a month of withdrawal (Joe et al. 2007). In contrast, elevated levels of serum BDNF were described in alcohol patients after shorter durations of abstinence (Huang et al. 2008; Chul et al. 2009). Further, BDNF serum levels were associated with withdrawal severity during early alcohol withdrawal, but while negative association was reported in one study (Heberlein et al. 2010), positive association was observed in another (Huang et al. 2008). This discrepancy was suggested to result from heritable and environmental variables (Joe et al. 2007; Nubukpo et al. 2017; Sharma et al. 2017). Finally, Heberlein et al. (2015) reported on increased methylation rates of the BDNF promotor of alcoholic patients during early withdrawal, compared with healthy controls, and decrease in methylation during the withdrawal period. Taken together, these findings showing alterations in peripheral BDNF levels during the abstinence period may expand the findings from animal models, suggesting a potential role of BDNF in the maintenance of abstinence. 
Table 1. Effects of alcohol on BDNF expression

\begin{tabular}{|c|c|c|c|}
\hline Treatment regimen & BDNF expression & Effect & References \\
\hline \multirow{4}{*}{$\begin{array}{l}\text { Acute administration }(2 \mathrm{mg} / \mathrm{kg}), 45 \mathrm{~min} \\
\text { after injection }\end{array}$} & mRNA: & & McGough et al. \\
\hline & Hippocampus & $\uparrow$ & 2004 \\
\hline & Dorsal striatum & $\uparrow$ & \\
\hline & $\mathrm{PFC}$ & - & \\
\hline \multirow[t]{4}{*}{ Voluntary consumption (10\% 2-BC), $4 \mathrm{wk}$} & mRNA: & & McGough et al. \\
\hline & Hippocampus & - & 2004 \\
\hline & Dorsal striatum & $\uparrow$ & \\
\hline & $\mathrm{PFC}$ & - & \\
\hline \multirow{3}{*}{$\begin{array}{l}\text { Voluntary consumption ( } 10 \% \text { alcohol in } \\
\text { operant self-administration), } 5 \mathrm{wk}\end{array}$} & mRNA: & & Jeanblanc et al. \\
\hline & DLS & $\uparrow$ & 2009 \\
\hline & DMS & $\uparrow$ & \\
\hline Chronic exposure to alcohol vapor, $4 \mathrm{wk}$ & mRNA: & & Tapia-Arancibia \\
\hline \multirow{5}{*}{ After alcohol exposure } & Hippocampus CA1 & $\downarrow$ & et al. 2001 \\
\hline & Hippocampus dentate gyrus & $\downarrow$ & \\
\hline & Hippocampus CA2 & - & \\
\hline & Hippocampus CA3 & - & \\
\hline & Hypothalamic supraoptic nucleus & $\downarrow$ & \\
\hline \multirow[t]{5}{*}{ After $12 \mathrm{~h}$ of withdrawal } & Hippocampus CA1 & $\downarrow$ & \\
\hline & Hippocampus dentate gyrus & - & \\
\hline & Hippocampus CA2 & - & \\
\hline & Hippocampus CA3 & $\uparrow$ & \\
\hline & Hypothalamic supraoptic nucleus & $\uparrow$ & \\
\hline \multirow{2}{*}{$\begin{array}{l}\text { Chronic intermittent ethanol (CIE) } \\
\text { exposure }\end{array}$} & Protein: & & Haun et al. 2018 \\
\hline & mPFC, dependent mice vs. nondependent & $\downarrow$ & \\
\hline \multirow[t]{4}{*}{ Withdrawal from alcohol liquid diet } & Protein: & & Alele and Devaud \\
\hline & Hippocampus & $\uparrow$ & 2013 \\
\hline & Cingulate cortex & $\uparrow$ & \\
\hline & Motor cortex & $\uparrow$ & \\
\hline \multirow[t]{4}{*}{ Alcohol liquid diet } & Protein: & & Miller 2004; Miller \\
\hline & Hippocampus & $\downarrow$ & and Mooney \\
\hline & Parietal cortex & $\uparrow$ & 2004 \\
\hline & Septum & $\uparrow$ & \\
\hline \multirow{7}{*}{$\begin{array}{l}\text { Withdrawal from alcohol consumption } \\
\text { (2-BC), after } 8 \mathrm{~d} \text { of withdrawal } \\
\text { Voluntary consumption (10\% 2-BC), } \\
3 \text { wk }\end{array}$} & BDNF: & & Briones and \\
\hline & Hippocampus & $\downarrow$ & Woods 2013 \\
\hline & mRNA: & & Stragier et al. 2015 \\
\hline & Hippocampus & & \\
\hline & exons II, III, VI IX & $\uparrow$ & \\
\hline & exon VIII & $\downarrow$ & \\
\hline & exons I, IV & - & \\
\hline \multirow{2}{*}{$\begin{array}{l}\text { Voluntary consumption (10\% 2-BC), } \\
3 \mathrm{wk}\end{array}$} & Protein: & & Stragier et al. 2015 \\
\hline & Hippocampus & $\uparrow$ & \\
\hline \multirow{3}{*}{$\begin{array}{l}\text { Voluntary consumption (single session of } \\
10 \% \text { alcohol in limited } 4 \text {-h access } 2-B C \text { ) }\end{array}$} & mRNA: & & Logrip et al. 2009 \\
\hline & Dorsal striatum & $\uparrow$ & \\
\hline & NAc & - & \\
\hline \multirow{7}{*}{$\begin{array}{l}\text { Voluntary consumption (10\% alcohol in } \\
\text { limited 4-h access 2-BC), } 6 \mathrm{wk}\end{array}$} & mRNA: & & Logrip et al. 2009 \\
\hline & Dorsal striatum & - & \\
\hline & NAc & - & \\
\hline & Dorsal PFC & - & \\
\hline & Ventral PFC & $\downarrow$ & \\
\hline & Frontal cortex & $\downarrow$ & \\
\hline & Posterior cortex & $\downarrow$ & \\
\hline
\end{tabular}




\section{Liran et al.}

Table 1. Continued

\begin{tabular}{|c|c|c|c|}
\hline Treatment regimen & BDNF expression & Effect & References \\
\hline $\begin{array}{l}\text { Voluntary consumption ( } 10 \% \text { alcohol in } \\
\text { limited } 4 \text {-h access } 2-B C) \text {, after } 2 \text { wk of } \\
\text { deprivation }\end{array}$ & $\begin{array}{l}\text { mRNA: } \\
\text { Dorsal PFC } \\
\text { Ventral PFC } \\
\text { Frontal cortex } \\
\text { Posterior cortex }\end{array}$ & $\begin{array}{l}- \\
- \\
\uparrow\end{array}$ & Logrip et al. 2009 \\
\hline $\begin{array}{l}\text { Voluntary consumption (10\% alcohol in } \\
\text { limited } 4 \text {-h access } 2-\mathrm{BC}) \text {, after a } \\
\text { postdeprivation session of alcohol } \\
\text { access }\end{array}$ & $\begin{array}{l}\text { mRNA: } \\
\text { Dorsal PFC } \\
\text { Ventral PFC } \\
\text { Frontal cortex } \\
\text { Posterior cortex }\end{array}$ & $\begin{array}{l}- \\
- \\
\downarrow \\
\downarrow\end{array}$ & Logrip et al. 2009 \\
\hline $\begin{array}{l}\text { Voluntary consumption ( } 5 \% \text { alcohol } \\
\text { 2-BC), } 15 \mathrm{~d}\end{array}$ & $\begin{array}{l}\text { mRNA: } \\
\text { DLS } \\
\text { DMS }\end{array}$ & $\begin{array}{l}\downarrow \\
-\end{array}$ & $\begin{array}{l}\text { Bahi and Dreyer } \\
\quad 2013\end{array}$ \\
\hline Voluntary consumption (IA2BC), 7 wk & $\begin{array}{l}\text { mRNA: } \\
\text { mPFC }\end{array}$ & $\downarrow$ & Darcq et al. 2015 \\
\hline Voluntary consumption (10\% 2-BC), $21 \mathrm{~d}$ & $\begin{array}{l}\text { mRNA: } \\
\text { mPFC }\end{array}$ & - & Darcq et al. 2015 \\
\hline Voluntary consumption (IA2BC), $7 \mathrm{wk}$ & $\begin{array}{l}\text { TrkB: } \\
\text { DLS } \\
\text { DMS } \\
\text { p75NTR in total homogenate: } \\
\text { DLS } \\
\text { DMS } \\
\text { p75NTR synaptosomal fraction levels of: } \\
\text { DLS } \\
\text { Binge } \\
\text { Session end/withdrawal } \\
\text { DMS }\end{array}$ & $\begin{array}{l}\downarrow \\
\uparrow \\
-\end{array}$ & Darcq et al. 2016 \\
\hline Acute administration $(1.5 \mathrm{~g} / \mathrm{kg})$ & $\begin{array}{l}\text { TrkB: } \\
\text { DLS } \\
\text { p75NTR: } \\
\text { DLS }\end{array}$ & - & Darcq et al. 2016 \\
\hline Voluntary consumption (10\% 2-BC), $21 \mathrm{~d}$ & $\begin{array}{l}\text { TrkB: } \\
\text { DLS } \\
\text { p75NTR: } \\
\text { DLS }\end{array}$ & - & Darcq et al. 2016 \\
\hline Alcohol-preferring $(\mathrm{P})$ rats & $\begin{array}{l}\text { Protein: } \\
\text { Amygdala }\end{array}$ & $\downarrow$ & $\begin{array}{l}\text { Prakash et al. } \\
\text { 2008; Moonat } \\
\text { et al. } 2011\end{array}$ \\
\hline Acute administration & $\begin{array}{l}\text { Protein: } \\
\text { Amygdala }\end{array}$ & $\uparrow$ & Pandey et al. 2008 \\
\hline $\begin{array}{l}\text { Withdrawal from alcohol dependence } \\
\text { (liquid diet) }\end{array}$ & $\begin{array}{l}\text { Protein: } \\
\text { Amygdala }\end{array}$ & $\downarrow$ & You et al. 2014 \\
\hline CIE vapor exposure ( 4 weekly cycles), 4 wk & $\begin{array}{l}\text { Bdnf mRNA: } \\
\text { Dorsomedial PFC } \\
\text { 3-d post-CIE } \\
\text { 7-d post-CIE } \\
\text { Central amygdala } \\
\text { 3-d post-CIE } \\
\text { 7-d post-CIE }\end{array}$ & $\begin{array}{l}\downarrow \\
\downarrow \\
\downarrow \\
\downarrow\end{array}$ & $\begin{array}{l}\text { Solomon et al. } \\
\quad 2019\end{array}$ \\
\hline
\end{tabular}


Table 1. Continued

\begin{tabular}{llll}
\hline Treatment regimen & BDNF expression & Effect & References \\
\hline Hippocampus & & \\
3-d post-CIE & $\downarrow$ & \\
7-d post-CIE & - \\
\hline
\end{tabular}

$(\uparrow)$ increase, $(\downarrow)$ decrease.

(BDNF) Brain-derived neurotrophic factor, (mRNA) messenger RNA, (PFC) prefrontal cortex, (mPFC) medial PFC, (DLS) dorsolateral striatum, (DMS) dorsomedial striatum, (2-BC) 2-bottle choice, (NAc) nucleus accumbens, (IA2BC) intermittent access to $20 \%$ alcohol 2-bottle choice.

BDNF and the Regulation of Alcohol Consumption

Manipulations increasing or decreasing BDNF expression have been shown in animal models to modulate alcohol consumption and have suggested a role for BDNF in the suppression of alcohol intake (see Table 2 for a summary).

Numerous lines of investigation have raised the possibility that BDNF keeps alcohol intake in moderation. Specifically, mice expressing approximately half the normal level of BDNF in the brain showed elevated alcohol intake both under baseline conditions (Hensler et al. 2003) and after a period of abstinence (McGough et al. 2004). Heterozygote of BDNF knockout mice also exhibit higher alcohol-induced sensitization and increased preference for an alcoholpaired location, relative to wild-type (WT) mice (McGough et al. 2004). Similarly, mice heterozygous for the transcription factor CREB have a reduced level of BDNF and higher alcohol preference, compared to WT mice (Pandey et al. 2004). Furthermore, conditional deletion of BDNF in mice postnatally (Rios et al. 2001) resulted in elevated alcohol intake (Logrip et al. 2015).

Furthermore, systemic or intradorsal striatum administration of RACK1, a protein that increases BDNF levels (Yaka et al. 2003; McGough et al. 2004; He et al. 2010; Neasta et al. 2012), reduced alcohol intake in mice and rats (McGough et al. 2004; Jeanblanc et al. 2006). Conversely, both BDNF haploinsufficiency (McGough et al. 2004) and the Trk inhibitor K252a (Jeanblanc et al. 2006) prevented the effect of Tat-RACK1 on alcohol drinking. Thus, these data demonstrate an inverse association between BDNF expression and alcohol consumption, likely conveyed via BDNF's action in the dorsal striatum.

Further studies have demonstrated that BDNF's actions to suppress alcohol intake are localized to the DLS. Specifically, infusion of recombinant BDNF into the DLS of rats decreased alcohol self-administration (Jeanblanc et al. 2009). In contrast, down-regulation of the endogenous BDNF in this brain region via viral-mediated delivery of RNAi targeting the $B d n f$ gene increased rat alcohol self-administration (Jeanblanc et al. 2009). In line with these findings, short hairpin RNA (shRNA)-mediated knockdown of Bdnf in the DLS, but not in the DMS, also promoted the development of excessive alcohol drinking in rats (Jeanblanc et al. 2009; Logrip et al. 2015). Moreover, infusion of BDNF into the adjacent NAc did not affect alcohol intake. Furthermore, the effect of BDNF in the DLS is specific for alcohol and does not generalize to other consummatory behaviors, as sucrose consumption is unaltered upon the manipulation of BDNF signaling in the DLS of rats (Jeanblanc et al. 2009; Darcq et al. 2015). Together, these data support a role for endogenous BDNF in the DLS in maintaining moderate levels of alcohol intake.

Interestingly, the suppression of alcohol self-administration by intra-DLS administration of BDNF occurred after $3 \mathrm{~h}$ (Jeanblanc et al. 2009), a time point indicative of a mechanism requiring downstream signaling and transcription/translation. Indeed, inhibition of protein synthesis prevented the suppression of alcohol self-administration by intra-DLS BDNF infu- 


\section{Liran et al.}

Table 2. Effects of BDNF-related manipulations on alcohol-related behaviors

\begin{tabular}{|c|c|c|c|}
\hline BDNF manipulation & Behavioral procedure & Effect & References \\
\hline$B d n f^{+/-}$mice & $\begin{array}{l}\text { Alcohol consumption and preference } \\
(2-B C)\end{array}$ & $\uparrow$ & $\begin{array}{l}\text { Hensler et al. } \\
2003\end{array}$ \\
\hline \multirow[t]{2}{*}{$B d n f^{+/-}$mice } & $\mathrm{CPP}$ & $\uparrow$ & McGough et al. \\
\hline & $\begin{array}{l}\text { Alcohol consumption after } \\
\text { withdrawal }(2-B C)\end{array}$ & $\uparrow$ & 2004 \\
\hline \multirow[t]{5}{*}{$B d n f^{+/-}$mice } & $\begin{array}{l}10 \% \text { alcohol operant self- } \\
\text { administration }\end{array}$ & - & $\begin{array}{l}\text { Hogarth et al. } \\
2013\end{array}$ \\
\hline & $\begin{array}{l}\text { Active-lever presses during } \\
\text { acquisition sessions }\end{array}$ & - & \\
\hline & $\begin{array}{l}\text { Breakpoint during progressive-ratio } \\
\text { sessions }\end{array}$ & - & \\
\hline & $\begin{array}{l}\text { Active lever presses during extinction } \\
\text { sessions }\end{array}$ & - & \\
\hline & $\begin{array}{l}\text { Active lever presses during cue and } \\
\text { alcohol-induced reinstatement } \\
\text { sessions }\end{array}$ & $\begin{array}{l}\uparrow \\
\text { (females only) }\end{array}$ & \\
\hline Inhibition of the BDNF signaling & Alcohol consumption (10\% 2-BC): & & Jeanblanc et al. \\
\hline pathway using Trk receptor & $B d n f^{+/+}$mice & $\uparrow$ & 2006 \\
\hline inhibitor K252a & $B d n f^{+/-}$mice & - & \\
\hline $\begin{array}{l}\text { Increased BDNF expression via Tat- } \\
\text { RACK1 }\end{array}$ & $\begin{array}{l}\text { Alcohol consumption and preference } \\
\quad(2-B C)\end{array}$ & $\downarrow$ & $\begin{array}{l}\text { McGough et al. } \\
2004\end{array}$ \\
\hline $\begin{array}{l}\text { Increased BDNF expression via Tat- } \\
\text { RACK1 }\end{array}$ & Alcohol-induced locomotor activity & $\downarrow$ & $\begin{array}{l}\text { McGough et al. } \\
2004\end{array}$ \\
\hline $\begin{array}{l}\text { Increased BDNF expression via Tat- } \\
\text { RACK1 into the dorsal striatum }\end{array}$ & $\begin{array}{l}\text { Alcohol consumption ( } 10 \% \text { alcohol } \\
\text { in operant self-administration) }\end{array}$ & $\downarrow$ & $\begin{array}{l}\text { Jeanblanc et al. } \\
2006\end{array}$ \\
\hline $\begin{array}{l}\text { Increased BDNF expression via Tat- } \\
\text { RACK1 }(1 \mu \mathrm{m} \text {, weekly i.c.v. } \\
\text { injection) }\end{array}$ & Alcohol consumption (10\% 2-BC) & $\downarrow$ & $\begin{array}{l}\text { McGough et al. } \\
2004\end{array}$ \\
\hline \multirow[t]{3}{*}{ Viral-mediated $B d n f$ knockdown } & $\begin{array}{l}\text { Alcohol consumption ( } 10 \% \text { alcohol } \\
\text { in operant self-administration): }\end{array}$ & & $\begin{array}{l}\text { Jeanblanc et al. } \\
2009\end{array}$ \\
\hline & Infusion into the DLS & $\uparrow$ & \\
\hline & Infusion into the DMS & - & \\
\hline \multirow[t]{4}{*}{ BDNF infusion } & $\begin{array}{l}\text { Alcohol consumption ( } 10 \% \text { alcohol } \\
\text { in operant self-administration, } 3 \mathrm{~h} \\
\text { after infusion): }\end{array}$ & & $\begin{array}{l}\text { Jeanblanc et al. } \\
2009,2013\end{array}$ \\
\hline & Infusion into the DLS & $\downarrow$ & \\
\hline & Infusion into the DMS & $\downarrow$ & \\
\hline & Infusion into the NAc shell & - & \\
\hline \multirow{6}{*}{$\begin{array}{l}\text { Infusion of BDNF antisense ONDs/ } \\
\text { BDNF sense ONDs/BDNF+ } \\
\text { BDNF antisense ODNs/BDNF }\end{array}$} & Alcohol preference (7\% 2-BC) & & Pandey et al. \\
\hline & Infusion into the central amygdala: & & 2006 \\
\hline & $B d n f$ antisense ODNs & $\begin{array}{l}\uparrow \text { (antagonized by } \\
\text { coinfusion of } \\
\text { BDNF) }\end{array}$ & \\
\hline & $\begin{array}{l}\text { Infusion into the medial amygdala: } \\
B d n f \text { antisense ODNs }\end{array}$ & $\begin{array}{l}\uparrow \text { (antagonized by } \\
\text { coinfusion of } \\
\text { BDNF) }\end{array}$ & \\
\hline & $\mathrm{BDNF}$ & $\downarrow$ & \\
\hline & $\begin{array}{l}\text { Infusion into the basolateral } \\
\text { amygdala }\end{array}$ & - & \\
\hline
\end{tabular}


Table 2. Continued

\begin{tabular}{|c|c|c|c|}
\hline BDNF manipulation & Behavioral procedure & Effect & References \\
\hline $\begin{array}{l}\text { Bilateral infusion of BDNF } \\
\quad(0.50 \mu \mathrm{g}) \text { into } \mathrm{mPFC} \text { of dependent } \\
\text { or nondependent mice }\end{array}$ & $\begin{array}{l}\text { Alcohol intake }(15 \% 2-\mathrm{BC}) \\
\text { Dependent mice injected with BDNF } \\
\text { vs. dependent mice injected with } \\
\text { vehicle }\end{array}$ & $\downarrow$ & $\begin{array}{l}\text { Haun et al. } \\
\quad 2018\end{array}$ \\
\hline $\begin{array}{l}\text { Viral-mediated overexpression of } \\
\text { Bdnf in the mPFC }\end{array}$ & $\begin{array}{l}\text { Dependence-driven escalation of } \\
\text { alcohol drinking (15\% 2-BC) }\end{array}$ & $\downarrow$ & $\begin{array}{l}\text { Haun et al. } \\
2018\end{array}$ \\
\hline $\begin{array}{l}\text { Viral-mediated BDNF overexpression } \\
\text { or down-regulation of miR124a in } \\
\text { the DLS }\end{array}$ & $\begin{array}{l}\text { CPP } \\
B d n f \text { overexpression: } \\
\text { LV-Bdnf } \\
\text { LV-siR124a } \\
\text { Bdnf knockdown: } \\
\text { LV-miR124a }\end{array}$ & $\begin{array}{l}\downarrow \\
\downarrow\end{array}$ & $\begin{array}{l}\text { Bahi and } \\
\text { Dreyer } 2013\end{array}$ \\
\hline $\begin{array}{l}B d n f \text { knockdown via viral-mediated } \\
\text { down-regulation of miR124a in the } \\
\text { DLS }\end{array}$ & $\begin{array}{l}\text { Alcohol consumption }(5 \% \text { 2-BC) } \\
\text { Bdnf overexpression: } \\
\text { LV-BDNF } \\
\text { LV-siR124a } \\
\text { Bdnf knockdown: } \\
\text { LV-miR124a }\end{array}$ & $\begin{array}{l}\downarrow \\
\downarrow\end{array}$ & \\
\hline $\begin{array}{l}\text { Bdnf knockdown via viral-mediated } \\
\text { overexpression of miR-206 in the } \\
\text { mPFC }\end{array}$ & $\begin{array}{l}\text { Alcohol consumption (10\% alcohol } \\
\text { in operant self-administration) }\end{array}$ & $\uparrow$ & $\begin{array}{l}\text { Tapocik et al. } \\
2014\end{array}$ \\
\hline $\begin{array}{l}B d n f \text { knockdown via viral-mediated } \\
\text { overexpression of miR-30a-5p in } \\
\text { the mPFC }\end{array}$ & Alcohol consumption (IA2BC) & $\uparrow$ & $\begin{array}{l}\text { Darcq et al. } \\
2015\end{array}$ \\
\hline $\begin{array}{l}\text { BDNF overexpression via miR-30a- } \\
5 \mathrm{p} \text { inhibition in the mPFC (after } \\
7 \mathrm{wk} \text { of IA2BC) }\end{array}$ & $\begin{array}{l}\text { Alcohol consumption and preference } \\
\text { (IA2BC) }\end{array}$ & $\downarrow$ & $\begin{array}{l}\text { Darcq et al. } \\
\quad 2015\end{array}$ \\
\hline $\begin{array}{l}\text { BDNF infusion into the DLS of rat } \\
\text { with a history of IA2BC }\end{array}$ & $\begin{array}{l}\text { Alcohol consumption }(20 / 10 / 2.5 \% \\
\text { alcohol in operant self- } \\
\text { administration, } 3 \text { h after BDNF } \\
\text { infusion) }\end{array}$ & - & $\begin{array}{l}\text { Darcq et al. } \\
\quad 2016\end{array}$ \\
\hline $\begin{array}{l}\text { Viral-mediated p75NTR knockdown } \\
\text { after } 7 \text { wk of IA2BC }\end{array}$ & $\begin{array}{l}\text { Alcohol consumption (IA2BC, } 4 \mathrm{wk} \\
\text { after virus infection) }\end{array}$ & $\downarrow$ & $\begin{array}{l}\text { Darcq et al. } \\
2016\end{array}$ \\
\hline $\begin{array}{l}\text { Intra-DLS infusion of LM11A-31 } \\
\text { ( } \mathrm{p} 75 \mathrm{NTR} \text { modulator) after } 7 \mathrm{wk} \text { of } \\
\text { IA2BC }\end{array}$ & $\begin{array}{l}\text { Alcohol consumption (IA2BC, } 2 \mathrm{~h} \\
\text { after LM11A-31 infusion) }\end{array}$ & $\downarrow$ & $\begin{array}{l}\text { Darcq et al. } \\
\quad 2016\end{array}$ \\
\hline $\begin{array}{l}\text { Systemic administration of LM11A- } \\
31 \text { after } 7 \text { wk of IA2BC }\end{array}$ & $\begin{array}{l}\text { Alcohol consumption (IA2BC, } 2 \mathrm{~h} \\
\text { after LM11A-31 administration) }\end{array}$ & $\downarrow$ & $\begin{array}{l}\text { Darcq et al. } \\
2016\end{array}$ \\
\hline Met68BDNF knockin mice & $\begin{array}{l}\text { Alcohol consumption and preference } \\
\quad(10 \% \text { IA2BC) } \\
\text { Alcohol consumption and preference } \\
\text { (20\% IA2BC) } \\
\text { Alcohol + quinine consumption and } \\
\text { preference (10\% IA2BC) } \\
\text { Alcohol + quinine consumption and } \\
\text { preference ( } 20 \% \text { IA2BC) }\end{array}$ & $\begin{array}{l}- \\
\uparrow \\
\uparrow \\
\uparrow\end{array}$ & $\begin{array}{l}\text { Warnault et al. } \\
2016\end{array}$ \\
\hline
\end{tabular}


M. Liran et al.

Table 2. Continued

\begin{tabular}{|c|c|c|c|}
\hline BDNF manipulation & Behavioral procedure & Effect & References \\
\hline $\begin{array}{l}\text { Viral-mediated overexpression of } \\
\text { wild-type Val68BDNF in the } \\
\text { vmPFC in Met68BDNF knockin } \\
\text { mice }\end{array}$ & $\begin{array}{l}\text { Alcohol consumption and preference } \\
\text { (10\% IA2BC + quinine, } 5 \mathrm{~d} \text { after } \\
\text { infusion) }\end{array}$ & $\downarrow$ & $\begin{array}{l}\text { Warnault et al. } \\
2016\end{array}$ \\
\hline $\begin{array}{l}\text { Systemic administration of the TrkB } \\
\text { activator, LM22A-4 in } \\
\text { Met68BDNF knockin mice }\end{array}$ & $\begin{array}{l}\text { Alcohol consumption and preference } \\
\text { (10\% IA2BC + quinine, } \\
\text { immediately after LM22A-4 } \\
\text { administration) }\end{array}$ & $\downarrow$ & $\begin{array}{l}\text { Warnault et al. } \\
2016\end{array}$ \\
\hline
\end{tabular}

$(\uparrow)$ increase, $(\downarrow)$ decrease.

(BDNF) Brain-derived neurotrophic factor, (2-BC) 2-bottle choice, (CPP) conditioned place preference, (DLS) dorsolateral striatum, (DMS) dorsomedial striatum, (NAc) nucleus accumbens, (ODNs) oligodeoxynucleotides, (PFC) prefrontal cortex, (mPFC) medial PFC, (LV) lentivirus, (IA2BC) intermittent access to 20\% alcohol 2-bottle choice.

sion (Jeanblanc et al. 2013). Inhibition of the ERK1/2 pathway, prevented BDNF-induced decreases in alcohol self-administration, with no similar effects of PLC $\gamma$ or PI3K inhibitors (Jeanblanc et al. 2013), suggesting that activation of the TrkB/ERK1/2 signaling pathway is necessary for the beneficial actions of BDNF on alcohol consumption. Moreover, the mRNA expression of preprodynorphin (Logrip et al. 2008) and dopamine D3 receptor (Jeanblanc et al. 2006) are increased following BDNF or TatRACK1 treatment, and inhibition of dopamine D3 receptor (Jeanblanc et al. 2006) or of dynorphin's receptor, the $\kappa$-opioid receptor (Logrip et al. 2008), reduced the ability of Tat-RACK1 to decrease alcohol consumption. Together, these data demonstrate that BDNF in the DLS gates alcohol intake via TrkB-mediated activation of ERK1/2 signaling, which results in the increase in the downstream effectors, preprodynorphin and dopamine receptor D3, which act to suppress alcohol intake (Logrip et al. 2015).

Interestingly, infusion of BDNF into the DLS of rats trained to chronically consume excessive levels of alcohol had no effects on alcohol consumption, suggesting that repeated cycles of access to high amounts of alcohol followed by withdrawal, preclude the ability of striatal BDNF to gate the level of alcohol self-administration (Darcq et al. 2016). The breakdown in BDNF signaling in the DLS is likely to be mediated through the reduction in the contribution of TrkB and the recruitment of p75NTR (Darcq et al. 2016), a low-affinity BDNF receptor, which counteracts the actions of TrkB (Kraemer et al. 2014). In support of this possibility, RNA-mediated knockdown of the p75NTR gene in the DLS, as well as intra-DLS infusion or systemic administration of the p75NTR modulator LM11A-31, reduced binge-like alcohol drinking (Darcq et al. 2016).

The beneficial actions of BDNF on alcohol intake are likely to also be mediated by additional brain regions. Specifically, amygdalar BDNF repressed both anxiety-like behavior and alcohol intake (Pandey et al. 2006), suggesting a function for BDNF in the amygdala in regulating anxiety-modulated alcohol consumption. Moreover, knockdown of BDNF expression via antisense oligonucleotide infusion in the $\mathrm{MeA}$ and $\mathrm{CeA}$ increased alcohol intake and anxietylike behavior, which was reversed by BDNF infusion (Pandey et al. 2006). In the amygdala, BDNF likely reduces anxiety-like behavior and alcohol intake via increasing dendritic spine density (Moonat et al. 2011). A more recent study found that infusion of BDNF into the mPFC of alcohol-dependent mice decreased alcohol intake, and that viral-mediated overexpression of $B d n f$ in this brain region reduced drinking escalation in these mice (Haun et al. 2018).

Another mechanism for the breakdown in corticostriatal BDNF signaling involves miRNAs targeting BDNF. As mentioned above, excessive alcohol reduces $B d n f$ levels in the PFC via an miRNA-mediated mechanism in mice (Darcq et al. 2015) and rats (Tapocik et al. 
2014). Overexpression of miR-206 in the mPFC of rats (Tapocik et al. 2014) or miR30a$5 \mathrm{p}$ in the mPFC of mice (Darcq et al. 2015) increased alcohol consumption. Conversely, intramPFC infusion of an inhibitor of miR30a-5p function led to a significant reduction in excessive alcohol drinking and preference (Darcq et al. 2015).

Finally, human and mouse studies suggest that innate malfunction of $\mathrm{BDNF}$ signaling may contribute to the development of AUD. Specifically, a loss-of-function mutation in BDNF in humans (G196A; also known as polymorphism rs6265) produces an amino acid substitution (Val66Met) leading to reduced activity-dependent release of BDNF (Egan et al. 2003; Chen et al. 2004). Human studies suggest that the Val66Met polymorphism increases the susceptibility to develop AUD. Specifically, carriers of the mutation are associated with earlier onset of alcoholism (Matsushita et al. 2004) and higher risk of relapse (Wojnar et al. 2009; Ron and Berger 2018). Transgenic mice expressing the mouse polymorphism (Val68/Met) exhibit compulsive-like alcohol consumption (Warnault et al. 2016). Overexpression of the WT BDNF in the mPFC of mutant Val68/MetBDNF mice rescues the excessive, compulsive alcoholdrinking phenotype (Warnault et al. 2016). Compulsive alcohol use in the Val68/MetBDNF knockin mice was also rescued by a systemic administration of the TrkB agonist, LM22A-4 (Warnault et al. 2016), suggestive of a potential therapeutic approach to treat humans carrying the Met66BDNF allele.

\section{Summary-BDNF}

In summary, the data presented here suggest that the corticostriatal BDNF pathway plays a crucial role in the regulation of alcohol consumption, keeping it in moderation via activation of the BDNF signaling within the DLS. In contrast, the transition from moderate-to-high intake results from the breakdown of the corticostriatal BDNF pathway. The mechanisms underlying the brain region selectivity of BDNF's beneficial actions on alcohol consumption should be addressed in future studies. Addition- ally, the identification of new drugs targeting BDNF or its downstream effectors may provide new leads for the treatment of AUD.

\section{GDNF}

GDNF is a secreted growth factor, initially identified in a glial-derived cell line (Lin et al. 1993). GDNF is expressed throughout the CNS during development, and in the adult brain the growth factor is highly expressed in the striatum, thalamus, cortex, and hippocampus (Pochon et al. 1997; Ortega-de San Luis and Pascual 2016). GDNF signals through the receptor tyrosine kinase RET (Durbec et al. 1996). Activation of RET by GDNF also requires the presence of the coreceptor GDNF-family receptor $\alpha 1$ (GFRo1) (Jing et al. 1996; Airaksinen and Saarma 2002). GDNF signaling depends on the presence of GFR $\alpha 1$ and RET in lipid raft compartments within the plasma membrane (Tansey et al. 2000; Paratcha et al. 2001; Tsui et al. 2015). Ligation of GDNF to RET and GFR $\alpha 1$ triggers the activation of several intracellular signaling cascades: the MAPK/ERK, PI3K, and PLC $\gamma$ cascades (Airaksinen and Saarma 2002; Sariola and Saarma 2003). Interestingly, RET is highly expressed in the midbrain (Trupp et al. 1997; Glazner et al. 1998), whereas the distribution of GDNF and GFR $\alpha 1$ are much more widespread (Ortega-de San Luis and Pascual 2016). In brain regions deficient in RET, GDNF acts through alternate receptors, such as the adhesion proteins syndecan-3 (Bespalov et al. 2011) and the neuronal cell-adhesion molecule (NCAM) (Paratcha et al. 2003).

GDNF plays a vital role in neuron development (Airaksinen and Saarma 2002; Bespalov and Saarma 2007) and promotes axonal growth of hippocampal and cortical neurons by signaling through NCAM via a mechanism that is independent of RET (Paratcha et al. 2003). Postnatally, GDNF also regulates the activity of midbrain dopaminergic neurons. Specifically, GDNF is produced by striatal neurons (Pochon et al. 1997; Barroso-Chinea et al. 2005), and is retrogradely transported via dopaminergic neurons to the midbrain, namely, the SN (Tomac et al. 1995; Kordower et al. 2000) and VTA (Wang 
M. Liran et al.

et al. 2010), where the RET receptor is abundant (Trupp et al. 1997). Activation of GDNF signaling in the midbrain increases the spontaneous activity of dopaminergic neurons in both nigrostriatal and mesolimbic projections (Yang et al. 2001; Wang et al. 2010; Kumar et al. 2015), and infusion of GDNF into the VTA increases dopamine release in the NAc (Wang et al. 2010).

Given its regulatory effect on midbrain dopamine function, GDNF has been implicated as a potential treatment target to Parkinson's disease (Ibáñez and Andressoo 2017; Grondin et al. 2019). GDNF has also been suggested to be involved in several neuropsychiatric disorders in which the mesolimbic system plays an important role, including depression, anxiety, stress, and schizophrenia (Ibáñez and Andressoo 2017), and has been implicated as a key player in the regulation of intake of abused drugs (Carnicella and Ron 2009; Ghitza et al. 2010; Barak et al. 2019).

\section{Alcohol Regulation of GDNF Expression}

Studies in rodents indicate that $G d n f$ levels fluctuate in response to different regimens of alco- hol exposure (see Table 3). For instance, 1 week of alcohol drinking in the IA2BC procedure (Carnicella et al. 2014), increased Gdnf mRNA levels in the VTA of rats when assessed at the end of the last 24-h drinking session, relative to water-drinking controls (Ahmadiantehrani et al. 2014). Similarly, a single systemic injection of a nonhypnotic dose of alcohol increased $G d n f$ mRNA expression in the VTA, with no effects on the NAc (Ahmadiantehrani et al. 2014). Gdnf expression in the VTA was still increased when measured immediately after a 30 -min binge-like drinking session following 7 weeks of IA2BC training (Ahmadiantehrani et al. 2014). However, $G d n f$ levels in the VTA were down-regulated below the baseline of water-drinking controls in response to 7 weeks of IA2BC, when tested after a 24-h withdrawal period (Ahmadiantehrani et al. 2014). Together, these data suggest that $G d n f$ is an alcohol-responsive gene, which is up-regulated during short-term alcohol intake but down-regulated during withdrawal from excessive alcohol intake (Barak et al. 2019).

Notably, studies in humans reported elevated serum GDNF protein levels in individuals displaying mild-to-severe AUD (Lhullier et al.

Table 3. Effects of alcohol on GDNF expression

\begin{tabular}{llcc}
\hline Treatment regimen & GDNF expression & Effect & References \\
\hline Acute exposure $(1.8 \mathrm{~g} / \mathrm{kg})$ & mRNA: & & Ahmadiantehrani et al. \\
& VTA & $\uparrow$ & 2014 \\
& NAc & - & \\
& Protein: & & \\
Voluntary consumption (IA2BC), 1 wk & VTA & $\uparrow$ & \\
& mRNA: & & Ahmadiantehrani et al. \\
& VTA & $\uparrow$ & 2014 \\
Voluntary consumption (IA2BC), 7 wk & NAc & - & \\
& mRNA: & & Ahmadiantehrani et al. \\
Voluntary consumption (IA2BC), $7 \mathrm{wk}+24 \mathrm{~h}$ & mRNA: NAc & - & 2014 \\
deprivation & VTA & & Ahmadiantehrani et al. \\
& NAc & $\downarrow$ & 2014 \\
Voluntary consumption (IA2BC), $7 \mathrm{wk}+$ binge & mRNA: & & \\
drinking & VTA (“low drinkers”) & $\uparrow$ & Ahmadiantehrani et al. \\
& VTA (“excessive drinkers”) & $\uparrow$ & \\
\hline
\end{tabular}

$(\uparrow)$ increase, $(\downarrow)$ decrease.

(GDNF) Glial cell line-derived neurotrophic factor, (mRNA) messenger RNA, (VTA) ventral tegmental area, (NAc) nucleus accumbens, (IA2BC) intermittent access to $20 \%$ alcohol 2-bottle choice. 
2015), but reduced levels in alcohol-dependent individuals experiencing withdrawal (Heberlein et al. 2010), supporting the notion that the GDNF system is sensitive to voluntary alcohol intake, and that dysregulation of GDNF expression can be detected across species.

\section{Mesolimbic GDNF and the Regulation of Alcohol Consumption}

GDNF in the mesolimbic system plays a unique role in neuroadaptations underlying AUD (see Table 4). Specifically, infusion of recombinant GDNF into the rat VTA, an essential component of the brain reward circuitry (Volkow and Morales 2015), reduced lever pressing for alcohol (Carnicella et al. 2008). Moreover, intra-VTA infusion of GDNF also suppressed rat bingelike home cage alcohol intake, and the suppressive effects persisted $24 \mathrm{~h}$ and even $48 \mathrm{~h}$ after a single administration of the growth factor (Carnicella et al. 2009a; Barak et al. 2011a). Finally, intra-VTA infusion of GDNF also inhibited the postextinction reacquisition of operant alcohol self-administration, suggesting that the growth factor decreases relapse to alcohol consumption (Carnicella et al. 2008). Importantly, GDNF had no effect on the self-administration of sucrose (Carnicella et al. 2008), implying that the growth factor does not alter the general motivation to consume natural rewards.

GDNF was also shown to control the escalation in alcohol consumption in a chronic excessive alcohol-exposure protocol. Specifically, virus-mediated overexpression of GDNF in the NAc or VTA of rats blocked escalation from moderate-to-excessive alcohol drinking, as measured in the IA2BC procedure (Barak et al. 2015). Together, these data suggest that activation of the GDNF signaling pathway in the VTA

Table 4. Effects of GDNF-related manipulations on alcohol-related behaviors

\begin{tabular}{|c|c|c|c|}
\hline $\begin{array}{l}\text { GDNF } \\
\text { manipulation }\end{array}$ & Behavioral procedure & Effect & References \\
\hline \multirow{5}{*}{$\begin{array}{l}\text { Intra-VTA GDNF } \\
\text { infusion }(10 \mu \mathrm{g} / \\
\text { hemisphere })\end{array}$} & Alcohol consumption (2-BC) & $\downarrow$ & $\begin{array}{c}\text { Carnicella et al. 2009a; } \\
\text { Barak et al. 2011a }\end{array}$ \\
\hline & Operant self-administration & $\downarrow$ & $\begin{array}{l}\text { Carnicella et al. 2008; } \\
\text { Barak et al. 2011b }\end{array}$ \\
\hline & Reacquisition of operant self-administration (relapse test) & $\downarrow$ & Carnicella et al. 2008 \\
\hline & CPP (acquisition) & $\downarrow$ & Barak et al. 2011b \\
\hline & CPP (expression) & $\downarrow$ & Barak et al. 2011b \\
\hline \multirow{2}{*}{$\begin{array}{l}\text { Viral-mediated } \\
\text { GDNF } \\
\text { overexpression }\end{array}$} & In the NAc or VTA: & & Barak et al. 2015 \\
\hline & Escalation in alcohol consumption (IA2BC) & $\downarrow$ & \\
\hline \multirow{8}{*}{$\begin{array}{l}\text { Viral-mediated } \\
\text { GDNF } \\
\text { knockdown }\end{array}$} & In the VTA: & & $\begin{array}{l}\text { Ahmadiantehrani et al. } \\
2014\end{array}$ \\
\hline & Escalation in alcohol consumption (IA2BC) & $\uparrow$ & \\
\hline & In the NAc: & & Barak et al. 2015 \\
\hline & Escalation in alcohol consumption (IA2BC) & $\uparrow$ & \\
\hline & Relapse after abstinence (IA2BC) & $\uparrow$ & \\
\hline & Operant self-administration & $\uparrow$ & \\
\hline & Reinstatement of operant self-administration (relapse test) & $\uparrow$ & \\
\hline & Reacquisition of operant self-administration (relapse test) & $\uparrow$ & \\
\hline \multirow{2}{*}{$\begin{array}{c}\text { GDNF or GFR } \alpha 1 \\
\text { heterozygote } \\
\text { knockout mice }\end{array}$} & Relapse after abstinence (2-BC) & $\uparrow$ & Carnicella et al. 2009b \\
\hline & $\mathrm{CPP}$ & $\uparrow$ & \\
\hline
\end{tabular}


M. Liran et al.

produces a sustained reduction of alcoholdrinking behaviors.

To test the contribution of the endogenous GDNF system to alcohol-drinking phenotypes, GDNF expression in the VTA or NAc was knocked down by viral delivery of shRNA sequence targeting the Gdnf gene. Knockdown of $G d n f$ in either the VTA or NAc facilitated the escalation of IA2BC alcohol drinking compared to rats infected with a nonspecific control sequence in the same brain regions (Ahmadiantehrani et al. 2014; Barak et al. 2015). In line with these findings, GDNF heterozygote knockout (HET) mice, which show $\sim 50 \%$ reduction in GDNF protein expression (Griffin et al. 2006), consumed more alcohol than their WT littermates after a period of abstinence and exhibited increased alcohol-conditioned place preference (CPP), a measure of alcohol reward (Carnicella et al. 2009b). These findings could be linked to the observation that Gdnf HET mice exhibit higher levels of dopamine in the striatum (Airavaara et al. 2004). Taken together, these findings suggest that like BDNF, the endogenous GDNF system protects against the escalation to excessive alcohol drinking during the early stages of alcohol consumption, whereas long-term excessive alcohol exposure may lead to breakdown of this protective mechanism, resulting in the escalation of alcohol intake (Barak et al. 2019). Interestingly, reexposure to a context previously associated with nicotine decreased $G d n f$ expression in the VTA in 50\%, and was associated with long-lasting (3 month) increases in operant alcohol self-administration and relapse (Zipori et al. 2017). These findings suggest that breakdown of the GDNF pathway in the mesolimbic system may provide a common neuroadaptation underlying the comorbidity of nicotine and alcohol abuse.

Findings also point out that the endogenous GDNF is differentially expressed in low and high alcohol drinkers. Specifically, although the IA2BC procedure generally produces a high number of excessively drinking rats $(\sim 60 \%-$ $70 \%)$, not all rats develop this typical pattern of alcohol consumption (Carnicella et al. 2014). Thus, alcohol-drinking rats can be segregated into two distinct groups: those whose alcohol intake progressively increases over time (high drinkers), and those who maintain moderate alcohol consumption (low drinkers). Interestingly, although binge-like alcohol drinking increased Gdnf expression in the VTA in both groups, the effect was considerably stronger among low drinkers (Ahmadiantehrani et al. 2014). Although this effect is confounded by the fact that excessive drinkers consumed higher levels of alcohol during the binge-drinking period (Ahmadiantehrani et al. 2014), these results suggest that GDNF is more responsive to alcohol and thus presumably more functional in low drinkers, compared to high drinkers. This conclusion was further supported by a negative correlation between alcohol intake levels and $G d n f$ expression in the VTA (Barak et al. 2015). Interestingly, these data are in line with data from human studies, indicating that serum GDNF is reduced in humans undergoing alcohol withdrawal (Heberlein et al. 2010), suggesting that low serum levels of GDNF may be an indicator of susceptibility to relapse. Taken together, these findings suggest that the sensitivity of the GDNF expression system to alcohol determines the profile of drinking. Thus, variation in the GDNF gene, particularly modifications that would impair the GDNF response to alcohol, should be investigated further as a possible marker of AUD susceptibility.

GDNF-dependent regulation of alcohol intake was shown to be mediated by the ERK1/2 pathway in the VTA (Carnicella et al. 2008). Specifically, intra-VTA infusion of GDNF activated ERK1/2 in the VTA, and specific inhibition of this signaling cascade but not of the PI3K pathway prevented GDNF-mediated suppression of alcohol self-administration (Carnicella et al. 2008). PLC $\gamma$ inhibition in the VTA of rats reduced alcohol self-administration on its own, therefore it was impossible to conclude about the contribution of this pathway to the effects of GDNF on alcohol self-administration (Carnicella et al. 2008).

As described above, activation of GDNF signaling in the VTA produces a rapid increase in the spontaneous firing of VTA dopamine neurons (Wang et al. 2010), whereas withdrawal from alcohol reduces the activity of VTA neu- 
rons (Diana et al. 1993; Bailey et al. 2001; Shen 2003; Shen et al. 2007; Barak et al. 2015). In line with the notion that GDNF reverses alcohol's actions in the mesolimbic system, infusion of GDNF into the VTA reverses the reduction in rat VTA dopamine firing (Barak et al. 2015). Furthermore, alcohol withdrawal reduces dopamine tone in the NAc (Weiss et al. 1996; Barak et al. 2011b), and intra-VTA administration of GDNF adjusted dopamine efflux in the NAc of rats undergoing a short period of withdrawal from heavy alcohol use (Barak et al. 2011b). Together, these results support the possibility that GDNF reduces alcohol intake by increasing VTA dopamine neuronal excitability, therefore reversing allostatic alterations in the mesolimbic dopamine system associated with withdrawal from long-term consumption of high alcohol levels (Barak et al. 2019).

Although GDNF triggers dopamine release in the NAc (Wang et al. 2010; Barak et al. 2011a), GDNF itself is not rewarding (Barak et al. 2011a); therefore, it does not reduce alcohol consumption by substituting for alcohol reward. Specifically, intra-VTA infusion of GDNF did not lead to the expression of alcohol-CPP (Barak et al. 2011a), confirming that the growth factor is not rewarding. Furthermore, intra-VTA GDNF infusion disrupted both the acquisition and the expression of alcohol-CPP (Barak et al. 2011a), suggesting that the growth factor suppresses the reinforcing effects of alcohol, rather than generating reinforcing effects on its own. Finally, infusion of GDNF into the VTA also produced a downward shift in the dose-response curve for alcohol self-administration (Barak et al. 2011a), indicating that this growth factor does not substitute for or augment the rewarding effects of alcohol, but rather suppresses the motivation for alcohol seeking and drinking.

It is important to note that while the effects of GDNF on alcohol drinking are rapid, they persist for a long time (Carnicella et al. 2009a; Barak et al. 2019). It has been suggested that these long-term effects occur through an autoregulatory cycle, in which the binding of GDNF to its receptor induces GDNF expression ( $\mathrm{He}$ and Ron 2006). Specifically, GDNF treatment of the dopaminergic-like SH-SY5Y cell line in- duced long-lasting increases in the growth factor's levels, resulting in long-lasting activation of RET (He and Ron 2006). Furthermore, this autoregulatory positive feedback loop was also observed in vivo, as infusion of recombinant GDNF into the VTA of rats increased the expression of GDNF mRNA and protein for at least $48 \mathrm{~h}$ (Barak et al. 2011a). This long-term up-regulation of Gdnf mRNA expression was prevented by inhibition of protein synthesis, as well as by the down-regulation of $G d n f$ mRNA (Barak et al. 2011a). Together, these findings indicate that GDNF positively regulates its own expression, and that this process depends on de novo transcription and translation of the growth factor. The relevance of this autoregulatory loop was further demonstrated for alcohol intake, as the long-lasting attenuation of alcohol consumption by intra-VTA GDNF infusion was prevented by down-regulation of $G d n f$ mRNA levels in the VTA, as well as by inhibition of protein synthesis (Barak et al. 2011a). Together, these findings suggest that long-lasting suppression of alcohol consumption is mediated at least in part through an autoregulatory loop in which GDNF promotes its own expression and signaling.

\section{Summary-GDNF}

Because animal studies show that GDNF affects alcohol-drinking behaviors, and human studies found abnormal levels of GDNF in AUD patients (Heberlein et al. 2010; Lhullier et al. 2015), targeting GDNF signaling may provide a promising approach for the development of new drugs to treat AUD. A promising pharmacological approach is to suppress alcohol consumption via a GDNF message-inducer, which increases the endogenous levels of GDNF. This approach is expected to induce a long-lasting activation of GDNF signaling, as a result of the positive feedback loop of the growth factor (Barak et al. 2011a). Interestingly, the Food and Drug Administration (FDA)-approved drug cabergoline, was shown to increase the expression of GDNF in dopaminergic-like SH-SY5Y cells, resulting in activation of the downstream signaling pathway (Carnicella et al. 2009c). Systemic 
M. Liran et al.

administration of a single dose of cabergoline suppressed alcohol consumption in rodents via a GDNF-dependent mechanism (Carnicella et al. 2009c). Therefore, drugs like cabergoline, mimicking GDNF, can be potential pharmacotherapy to suppress excessive alcohol drinking and relapse.

\section{FGF2}

FGF2 is a member of the FGF family, consisting of 22 members (Chlebova et al. 2009; Förthmann et al. 2015). FGF2 is highly abundant throughout the neuronal tube from the early stages of embryonic development (Dono et al 1998; Ford-Perriss et al. 2001). FGF2 has been extensively studied for its role during development-in cell proliferation, differentiation, growth, survival, and angiogenesis (Dono et al. 1998; Ford-Perriss et al. 2001; Reuss and von Bohlen und Halbach 2003). In adulthood, FGF2 is expressed in both neurons and astrocytes (Gonzalez et al. 1995; Reuss and von Bohlen und Halbach 2003) in multiple brain regions, including the frontal cortex, thalamus, hypothalamus, striatum, hippocampus, amygdala, ventral midbrain (SN and VTA), and pons (Gonzalez et al. 1995; Reuss and von Bohlen und Halbach 2003). In adulthood, FGF2 has been implicated in learning and memory processes (Graham and Richardson 2011).

FGF2 binds to FGF receptor 1 (FGFR1), a receptor tyrosine kinase (Ford-Perriss et al. 2001). The binding of FGF2 to this receptor leads to receptor dimerization and to the activation of the receptor via autophosphorylation (Eswarakumar et al. 2005), resulting in the activation of the PLC $\gamma$, ERK1/2, and PI3K signaling (Numakawa et al. 2002; Reuss and von Bohlen und Halbach 2003; Eswarakumar et al. 2005; Peltier et al. 2007).

Malfunctioning of FGF2 signaling has been implicated in numerous neuropsychiatric disorders, including anxiety (Perez et al. 2009; ErenKoçak et al. 2011; Turner et al. 2012), depression (Mallei et al. 2002; Maragnoli et al. 2004; Riva et al. 2005; Elsayed et al. 2012; Turner et al. 2012), stress-related disorders (Molteni et al. 2001a,b; Fumagalli et al. 2005; Xia et al. 2013), and schizophrenia (Klejbor et al. 2006; van Scheltinga et al. 2010), as well as in neurodegenerative diseases (Cummings et al. 1993; Claus et al. 2004; Timmer et al. 2007; Kiyota et al. 2011). In addition, accumulating evidence suggests that FGF2 is involved in the behavioral and neurobiological effects of drugs of abuse, including cocaine, amphetamine, and nicotine (EvenChen and Barak 2019a).

\section{Alcohol Regulation of FGF2 Expression}

An acute alcohol injection $(2.5 \mathrm{~g} / \mathrm{kg})$ increased the mRNA expression of Fgf2 levels in the mouse dorsal striatum, NAc, and dorsal hippocampus (Even-Chen et al. 2017). Longer alcohol exposure $(2.5 \mathrm{~g} / \mathrm{kg}$ injection once a day for 7 days) limited these changes to the dorsal striatum at both its subregions, the DMS and the DLS, and these increases were found to be mediated by dopamine D2-like receptor activation (Even-Chen et al. 2017). The same 7-day exposure also up-regulated the mRNA expression of FGF2 receptor, Fgfr1, in the dorsal striatum and dorsal hippocampus (Even-Chen and Barak 2019b). Furthermore, voluntary consumption of $20 \%$ alcohol for 5-7 weeks increased Fgf2 and Fgfr 1 expression in the DMS, but not the DLS, of both mice and rats (Even-Chen et al. 2017; Even-Chen and Barak 2019b). Thus, although limited noncontingent exposure to alcohol leads to widespread increases in mesolimbic Fgf2/Fgfr1 expression, it seems that extended and/or voluntary alcohol consumption results in more spatially specific effects on the expression of the growth factor and its receptor (see Table 5 for a summary of the effects of alcohol on brain FGF2 expression).

\section{FGF2 and the Regulation of Alcohol Consumption}

Systemic administration of recombinant FGF2 to mice increases alcohol intake and preference, with no similar effects on the consumption of water or natural rewards (sweetened solution: sucrose or saccharin) (Even-Chen et al. 2017). Moreover, infusion of recombinant FGF2 into the DMS of rats increased alcohol consumption 
Table 5. Effects of alcohol on FGF2 expression

\begin{tabular}{|c|c|c|c|}
\hline Treatment regimen & FGF2 expression & Effect & References \\
\hline Acute exposure $(2.5 \mathrm{~g} / \mathrm{kg})$ & mRNA: & & Even-Chen et al. 2017 \\
\hline & Dorsal striatum, NAc, and hippocampus & $\uparrow$ & \\
\hline Subchronic exposure $(7 \times 2.5 \mathrm{~g} / \mathrm{kg})$ & $\begin{array}{l}\text { mRNA: } \\
\text { DMS and DLS }\end{array}$ & $\uparrow$ & Even-Chen et al. 2017 \\
\hline Voluntary consumption (IA2BC) & $\begin{array}{l}\text { mRNA: } \\
\text { DMS }\end{array}$ & $\uparrow$ & Even-Chen et al. 2017 \\
\hline Sucrose operant self-administration & $\begin{array}{l}\text { Protein: } \\
\text { Infralimbic PFC (after } 9 \text { withdrawal days) }\end{array}$ & - & Hafenbreidel et al. 2015 \\
\hline
\end{tabular}

$(\uparrow)$ increase, $(\downarrow)$ decrease.

(FGF2) Fibroblast growth factor 2, (mRNA) messenger RNA, (NAc) nucleus accumbens, (DMS) dorsomedial striatum, (DLS) dorsolateral striatum, (IA2BC) intermittent access to 20\% alcohol 2-bottle choice, (PFC) prefrontal cortex.

and preference. Inhibition of the PI3K, but not of the ERK1/2 signaling in the DMS, blocked the effects of FGF2 on alcohol intake and preference (Even-Chen and Barak 2019b), indicating that the effects of FGF2 are mediated, at least in part, via the PI3K pathway in the DMS.

In contrast, blocking FGF2 activity in the DMS with an anti-FGF2-neutralizing antibody suppressed alcohol intake and preference (EvenChen et al. 2017). Likewise, systemic administration of the FGFR1 inhibitor PD173074 to mice, as well as its infusion into the DMS of rats, decreased alcohol consumption and preference, with no effects on natural reward consumption (Even-Chen and Barak 2019b). Together, these data indicate that increasing the activity of FGF2-FGFR1 increases alcohol intake, where inhibition of the growth factor's activity reduces alcohol intake (see Table 6 for a summary of the effects of FGF2-related manipulations on alcohol-drinking behaviors).

\section{Summary-FGF2}

Taken together, these data suggest that FGF2 acts as a positive regulator of alcohol consumption and forms a positive feedback loop centered in the DMS, in which alcohol increases FGF2 levels, and FGF2, in turn, increases the consumption of alcohol. Although additional studies are required, it seems that inhibition of FGF2 production and/or its receptor's activity could be used to reduce alcohol consumption, providing a potential therapeutic target.

\section{MIDKINE, PLEIOTROPHIN, AND ALK}

The growth factors MDK and PTN (Wellstein 2012) bind to and activate the receptor tyrosine kinase ALK (Hallberg and Palmer 2016). Both MDK and PTN promote growth, survival, differentiation, and recovery of neurons (Herradón and Pérez-García 2014), and MDK was shown to promote the outgrowth of neurons and to inhibit neuronal apoptosis by activation of the PI3K and ERK1/2 pathways (Owada et al. 1999). High expression of ALK and its ligands was identified in the developing mouse central nervous system (CNS) (Morris et al. 1997). The growth factors and their receptor are also expressed, albeit to a lesser extent, in the adult mouse brain (Morris et al. 1997). Alk mRNA is almost exclusively expressed in the midbrain, thalamus, and olfactory bulb of embryonic and neonatal mice (Iwahara et al. 1997). ALK has been implicated in the pathogenesis of several types of cancer (Hallberg and Palmer 2013). In addition, the expression levels of brain MDK and PTN has been associated with drugs of abuse (Herradón and Pérez-García 2014).

\section{Alcohol Regulation of MDK/PTN Expression}

Only a few studies examined the effects of alcohol on MDK and PTN expression (Table 7). An acute alcohol injection ( $2 \mathrm{~g} / \mathrm{kg}$ i.p.) was reported to induce increases of $\sim 25 \%$ and $\sim 50 \%$ in Ptn mRNA and PTN protein levels in the PFC, re- 
M. Liran et al.

Table 6. Effects of FGF2-related manipulations on alcohol-related behaviors

\begin{tabular}{|c|c|c|c|}
\hline FGF2 manipulation & Behavioral procedure & Effect & References \\
\hline \multirow[t]{2}{*}{$\begin{array}{l}\text { Systemic FGF2 injection } \\
\qquad(80 \mu \mathrm{g} / \mathrm{kg})\end{array}$} & $\begin{array}{l}\text { Alcohol consumption and preference } \\
\text { (IA2BC) }\end{array}$ & $\uparrow$ & Even-Chen et al. 2017 \\
\hline & Total fluids consumption & - & \\
\hline \multirow[t]{2}{*}{$\begin{array}{l}\text { Intra-DMS FGF2 infusion } \\
\text { (200 ng/hemisphere) }\end{array}$} & $\begin{array}{l}\text { Alcohol consumption and preference } \\
\text { (IA2BC) }\end{array}$ & $\uparrow$ & $\begin{array}{l}\text { Even-Chen et al. 2017; Even- } \\
\text { Chen and Barak 2019b }\end{array}$ \\
\hline & Total fluids consumption & - & \\
\hline \multirow[t]{2}{*}{$\begin{array}{l}\text { Anti-FGF2-neutralizing antibody } \\
\text { in the DMS }\end{array}$} & $\begin{array}{l}\text { Alcohol consumption and preference } \\
\text { (IA2BC) }\end{array}$ & $\downarrow$ & $\begin{array}{l}\text { Even-Chen et al. 2017; Even- } \\
\text { Chen and Barak 2019b }\end{array}$ \\
\hline & Total fluids consumption & - & \\
\hline \multirow[t]{2}{*}{ Systemic FGFR1 antagonist } & $\begin{array}{l}\text { Alcohol consumption and preference } \\
\text { (IA2BC) }\end{array}$ & $\downarrow$ & Even-Chen and Barak 2019b \\
\hline & Total fluids consumption & - & \\
\hline \multirow[t]{2}{*}{ Intra-DMS FGF2 antagonist } & $\begin{array}{l}\text { Alcohol consumption and preference } \\
\text { (IA2BC) }\end{array}$ & $\downarrow$ & Even-Chen and Barak 2019b \\
\hline & Total fluids consumption & - & \\
\hline $\begin{array}{l}\text { Systemic FGF2 injection }(80 \mu \mathrm{g} / \\
\mathrm{kg})\end{array}$ & $\begin{array}{l}\text { Sucrose and saccharin consumption and } \\
\text { preference }(2-B C)\end{array}$ & - & Even-Chen et al. 2017 \\
\hline
\end{tabular}

spectively (Vicente-Rodríguez et al. 2014b). In humans, increases in the mRNA and protein expression of MDK was found in the NAc and PFC tissues of AUD patients (Flatscher-Bader et al. 2005; Flatscher-Bader and Wilce 2006, 2008).

\section{Regulation of Alcohol-Related Behaviors by MDK/PTN/ALK}

The first evidence for the causal role of ALK in alcohol-related behaviors came from the finding that a loss-of-function mutation in ALK resulted in lower sensitivity of fruit flies to the acute sedating effect of alcohol (Lasek et al. 2011). Sim-

Table 7. Effects of alcohol on ALK expression

\begin{tabular}{llcc}
\hline $\begin{array}{l}\text { Treatment } \\
\text { regimen }\end{array}$ & \multicolumn{1}{c}{$\begin{array}{c}\text { ALK } \\
\text { expression }\end{array}$} & Effect & References \\
\hline $\begin{array}{c}\text { Acute alcohol } \\
\text { injection (2 }\end{array}$ & mRNA: & & $\begin{array}{c}\text { Vicente- } \\
\text { g/kg i.p.) }\end{array}$ \\
& Protein: & $\uparrow$ & $\begin{array}{l}\text { Rodríguez } \\
\text { et al. 2014b }\end{array}$ \\
& PFC & $\uparrow$ & \\
\hline
\end{tabular}

$(\uparrow)$ increase, $(\downarrow)$ decrease.

(ALK) Anaplastic lymphoma kinase, (mRNA) messenger RNA, (PFC) prefrontal cortex. ilarly, Alk knockout mice showed higher loss of righting reflex (LORR), also pointing to higher sensitivity to alcohol (Lasek et al. 2011). Alk knockout mice were also reported to consume more alcohol in a binge-like drinking test (Lasek et al. 2011; Schweitzer et al. 2016) and in operant alcohol self-administration (Mangieri et al. 2017) compared to WT mice. Alk knockout mice did not differ in the escalation of alcohol drinking after preexposure to alcohol in an intermittent alcohol vapor regimen (Schweitzer et al. 2016).

In contrast to the findings with Alk knockout mice, infection of the VTA of mice with viral-delivered shRNA targeting Alk reduced drinking in a 4-day alcohol DID test, compared to the control scrambled shRNA (Dutton et al. 2017). Similarly, the ALK inhibitors NVPTAE684 or alectinib, reduced alcohol consumption in the binge-like drinking test, with no similar effect on sucrose drinking (Dutton et al. 2017). In addition, NVP-TAE684 treatment prevented the acquisition of alcohol-CPP (Dutton et al. 2017). The authors suggested that the opposite effects on alcohol drinking between Alk knockout mice and the treatment with the ALK inhibitors or local knockdown of the gene, 
Table 8. Effects of ALK-related manipulations on alcohol-related behaviors

\begin{tabular}{|c|c|c|c|}
\hline ALK manipulation & Behavioral procedure & Effect & References \\
\hline \multirow[t]{2}{*}{ Alk ${ }^{-l-}$ mice } & Alcohol consumption (DID) & $\uparrow$ & Lasek et al. 2011 \\
\hline & LORR test & $\uparrow$ & \\
\hline Alk ${ }^{-/-}$mice & Operant alcohol self-administration & $\uparrow$ & Mangieri et al. 2017 \\
\hline Alk ${ }^{-/-}$mice & $\begin{array}{l}\text { Alcohol consumption (2-BC) followed by } \\
\text { chronic intermittent exposure }\end{array}$ & - & $\begin{array}{l}\text { Schweitzer et al. } \\
\quad 2016\end{array}$ \\
\hline \multirow[t]{2}{*}{ ALK inhibitors } & Binge-like alcohol consumption & $\downarrow$ & Dutton et al. 2017 \\
\hline & $\mathrm{CPP}$ & $\downarrow$ & \\
\hline $\begin{array}{l}\text { Viral-mediated down-regulation of Alk } \\
\text { in VTA }\end{array}$ & Binge-like alcohol consumption & $\downarrow$ & \\
\hline \multirow[t]{3}{*}{$M d k^{-1-}$ mice } & $\mathrm{CPP}$ & $\uparrow$ & Vicente-Rodríguez \\
\hline & Rotarod test & $\downarrow$ & et al. 2014a \\
\hline & LORR test & $\downarrow$ & \\
\hline \multirow[t]{2}{*}{$M d k^{-/-}$mice } & Alcohol consumption (2-BC) & $\uparrow$ & Chen et al. 2017 \\
\hline & Binge-like alcohol consumption & $\uparrow$ & \\
\hline $\begin{array}{l}\text { Viral-mediated down-regulation of } M d k \\
\text { in the VTA }\end{array}$ & Binge-like alcohol consumption & $\uparrow$ & \\
\hline $\mathrm{Ptn}^{-1-}$ mice & $\mathrm{CPP}$ & $\uparrow$ & $\begin{array}{l}\text { Fernández-Calle } \\
\text { et al. } 2019\end{array}$ \\
\hline \multirow[t]{3}{*}{$\mathrm{Ptn}^{-1-}$ mice } & $\mathrm{CPP}$ & $\uparrow$ & Vicente-Rodríguez \\
\hline & LORR test & - & et al. $2014 \mathrm{~b}$ \\
\hline & Rotarod test & $\uparrow$ & \\
\hline \multirow{3}{*}{$\begin{array}{l}\text { Cortex- and hippocampus-specific Ptn } \\
\text { overexpression (Ptn-Tg mice) }\end{array}$} & СРP & $\downarrow$ & \\
\hline & LORR test & $\downarrow$ & \\
\hline & Rotarod test & $\uparrow$ & \\
\hline
\end{tabular}

$(\uparrow)$ increase, $(\downarrow)$ decrease.

(ALK) Anaplastic lymphoma kinase, (DID) drinking in the dark, (LORR) loss of righting reflex, (2-BC) 2-bottle choice, (CPP) conditioned place preference, (VTA) ventral tegmental area.

may be a result of compensatory mechanisms in Alk knockout mice, which have global lower levels of ALK throughout embryonic development.

Similar to the results obtained with ALK manipulations, MDK and PTN were found to affect alcohol-related behaviors in animal models as well. Specifically, $M d k$ knockout mice consume less alcohol than WT controls, but the acquisition of alcohol-CPP was enhanced in $M d k$ knockout mice (Vicente-Rodríguez et al. 2014a). In addition, $M d k$ knockout mice showed delayed recovery from alcohol-induced ataxia, with no effect on LORR (Vicente-Rodríguez et al. 2014a). Down-regulation of MDK by viral-mediated delivery of shRNA in the VTA of mice also reduced alcohol consumption (Chen et al. 2017). Similar behavioral phenotypes were detected with Ptn knockout mice, which showed a stronger acquisition of alcohol-CPP compared to WT controls (Vicente-Rodríguez et al. 2014b;
Fernández-Calle et al. 2019). In contrast, alcohol-CPP was abolished in the Ptn transgenic (PTN-Tg) mice, in which Ptn is overexpressed in the cortex and hippocampus (Vicente-Rodríguez et al. 2014a). Both Ptn knockout and overexpressing mice showed reduced motor coordination in the rotarod test, and Ptn overexpressing mice showed longer time to recover in the LORR test (Vicente-Rodríguez et al. 2014a). Table 8 summarizes the effects of ALK-related manipulations on alcohol-related behaviors.

\section{Summary-Midkine, Pleiotrop, and ALK}

More data are required to clarify the role of the PTN and MDK in alcohol-related behaviors. The recent data indicating that genetic downregulation of ALK reduces alcohol drinking, and that ALK inhibitors are also suppressors of alcohol consumption in animal models, sug- 
M. Liran et al.

gest that ALK may provide a promising therapeutic target, although further research is needed to better characterize its potential.

\section{IGF-1}

IGF-1 is a 70-amino acid polypeptide hormone, structurally similar to insulin (Laron 2001). IGF-1 has been implicated in cell growth and survival, differentiation, proliferation, and maturation (Delafontaine et al. 2004). The expression of this growth factor is high mainly through developmental stages, and then slowly declines with age (Junnila et al. 2013). Its synthesis and secretion are mainly regulated by nutrient intake (Breese et al. 1991) and pituitary secretion of growth hormone $(\mathrm{GH})$ (Clemmons 2004). After secretion, IGF-1 binds to IGF-1 receptor (IGF-1R), a membrane-bound receptor tyrosine kinase. To establish the interaction between IGF-1 and its receptor, IGF-1 binds with high affinity to IGF-1-binding proteins (IGFBPs), present extracellularly (Allard and Duan 2018). Ligation of IGF-1 with IGF-1R activates the ERK1/2 and PI3K signaling pathways (Wrigley et al. 2017). While IGF-1 is primarily synthesized in the liver, it is also synthesized locally in almost every other organ, including brain regions related to neurogenesis, the olfactory bulb, cerebellum, and hippocampus (Wrigley et al. 2017).

\section{Alcohol Regulation of IGF-1 Expression}

Studies in rodents indicated alcohol-related changes of Igfl mRNA expression and IGF-1 protein levels in the brain (Table 9). For example, chronic alcohol liquid diet $(36 \%$ alcohol for $6 \mathrm{wk}$ ) reduced the mRNA expression levels of Igf- 1 in the temporal lobe (Cohen et al. 2007). In addition, IGF-1 protein levels were reduced in the hippocampus $48 \mathrm{~h}$ after binge-like alcohol exposure (oral gavage) in male and female rats, and 4 days of binge-like exposure reduced IGF-1 protein levels only in female rats (Maynard et al. 2018). Prenatal alcohol exposure of dams yielded higher whole brain Igf- 1 mRNA levels in the exposed offspring (Breese et al. 1994). In contrast, two other studies demonstrated that chronic prenatal exposure reduced Igf- 1 mRNA expression levels in the whole rat brain (Singh et al. 1996), and in the cerebellum (Soscia et al. 2006), with no change in the cerebellum in another study (de la Monte et al. 2005). Postnatal injections of alcohol to pups yielded no change in IGF-1 expression in the cerebellum, but elevated IGF-1R protein levels (Ewenczyk et al. 2012). Together, these findings suggest that IGF-1 levels are altered by alcohol exposure; however, more studies are required to better characterize these effects of alcohol on brain IGF-1 in adulthood, particularly after voluntary alcohol drinking.

Table 9. Effects of alcohol on IGF-1 expression

\begin{tabular}{|c|c|c|c|}
\hline Treatment regimen & IGF-1 expression & Effect & References \\
\hline \multirow[t]{2}{*}{ Liquid diet ( $37 \%$ for $6 \mathrm{wk})$} & mRNA: & & Cohen et al. 2007 \\
\hline & Temporal lobe & $\downarrow$ & \\
\hline \multirow[t]{2}{*}{ Oral gavage ( $5 \mathrm{mg} / \mathrm{kg} 3$ times/day for $4 \mathrm{~d}$ ) } & Protein: & & Maynard et al. 2018 \\
\hline & Hippocampus & $\downarrow$ & \\
\hline \multirow{2}{*}{$\begin{array}{l}\text { Postnatal exposure (i.p injections } 2 \mathrm{mg} / \mathrm{kg} / \text { day on } \\
\text { PND 2-8) }\end{array}$} & mRNA: & & Ewenczyk et al. 2012 \\
\hline & Cerebellum & - & \\
\hline \multirow[t]{2}{*}{ Chronic prenatal exposure } & mRNA: & & Soscia et al. 2006 \\
\hline & Cerebellum & $\downarrow$ & \\
\hline \multirow[t]{2}{*}{ Chronic prenatal exposure } & mRNA: & & de la Monte et al. 2005 \\
\hline & Cerebellum & - & \\
\hline \multirow[t]{2}{*}{ Chronic prenatal exposure } & mRNA: & & Singh et al. 1996 \\
\hline & Whole brain & $\downarrow$ & \\
\hline \multirow[t]{2}{*}{ Chronic prenatal exposure } & mRNA: & & Breese et al. 1994 \\
\hline & Whole brain & $\uparrow$ & \\
\hline
\end{tabular}

$(\uparrow)$ increase, $(\downarrow)$ decrease.

(IGF-1) Insulin-like growth factor 1, (mRNA) messenger RNA, (PND) postnatal day. 
Table 10. Effects of IGF-1-related manipulations on alcohol-related behaviors

\begin{tabular}{llcc}
\hline IGF-1 manipulation & \multicolumn{1}{c}{ Behavioral procedure } & Effect & Reference \\
\hline Intranasal delivery of IGF-1 in & Alcohol-induced locomotor activity & - & McGough et al. 2009 \\
postnatal rats & Alcohol-induced motor coordination & $\downarrow$ & \\
& Alcohol-related Morris water maze & - & \\
& spatial learning & & \\
\hline
\end{tabular}

$(\uparrow)$ increase, $(\downarrow)$ decrease.

(IGF-1) Insulin-like growth factor 1.

Interestingly, the effects of alcohol on IGF1 expression were also studied in healthy humans, as well as in individuals with AUD. Specifically, IGF-1 serum levels declined slightly $6 \mathrm{~h}$, whereas IGFBP-1 were increased $2 \mathrm{~h}$, after alcohol exposure in healthy humans (Röjdmark et al. 2000). Another study detected increases in IGFBP-1 levels, but no changes in IGF-1 serum levels in healthy individuals after alcohol exposure (Röjdmark et al. 2001). Moreover, the level of Igf 1 mRNA was reduced in the cerebellum of AUD patients (de la Monte et al. 2005). In line with this finding, IGF-1 serum levels were found to be reduced in individuals with AUD, compared to healthy individuals (Röjdmark and Brismar 2001; Leggio et al. 2008), even after protracted withdrawal (García-Marchena et al. 2017). Taken together, both animal and human studies point to deficient expression of IGF-1 following alcohol exposure.

\section{Regulation of Alcohol-Related Behaviors by IGF-1}

Using the parallel bar motor coordination test, it was demonstrated that intranasal delivery of IGF-1 on PND 10-13 reversed the impairing effects of neonatal alcohol exposure on motor coordination, but had no effects on abnormalities caused by alcohol exposure in spatial learning (as measured in the Morris water maze) and locomotor activity in rats (McGough et al. 2009). These findings suggest that IGF-1 may have potential beneficial effects against some of the early life harmful effects of alcohol exposure (see Table 10 for summary).

\section{Summary-IGF-1}

In summary, while some data indicate that IGF1 might interact with alcohol exposure, and that IGF-1 treatment may have beneficial effects in preventing the effects of alcohol, additional studies are required to establish the involvement of IGF-1 in alcohol-drinking behaviors and in AUD. Giving that IGF-1 was shown to cross the blood-brain barrier (Reinhardt and Bondy 1994), systemic administration of human IGF1 replacement therapies, may provide promising candidates in further explorations for AUD treatment. Thus, extensive research on the effects of IGF-1 on alcohol-related behaviors is needed.

\section{GENERAL SUMMARY AND CONCLUDING REMARKS}

We survey here the literature regarding the involvement of several growth factor systems in alcohol in AUD. We focused on two directions of the alcohol-growth factor interaction: the effects of alcohol on the expression of the growth factors (or their receptors), and regulation of alcohol-related behaviors by manipulations on the growth factor systems. While the reports are not always consistent, several conclusions can be drawn from this review.

We previously classified the molecular mechanisms that control alcohol-drinking behaviors into two clusters (Ron and Barak 2016). Specifically, we termed the signaling pathways that contribute to the transition from moderate-to-excessive alcohol consumption as "GO pathways," whereas the molecular pathways that promote resilience against escalation 
M. Liran et al.

of alcohol consumption and keep alcohol intake in moderation, as the "STOP pathways" (Ron and Barak 2016; Ron and Berger 2018). In the context of this classification, we can roughly sort the growth factors that we reviewed here into these two categories. Growth factors that belong to "STOP pathways" include GDNF in the mesolimbic systems (Barak et al. 2019) and BDNF in the corticostriatal system (Logrip et al. 2015). These growth factors belong in the "STOP pathways" category as activation of these systems suppress alcohol drinking. On the contrary, striatal FGF2 has been suggested to be a part of the "GO pathway," because elevation in the striatal levels of this growth factor were shown to increase alcohol intake, and its inactivation suppresses drinking (Even-Chen et al. 2017; EvenChen and Barak 2019a,b). The classification of MDK/PTN/ALK is less clear because of the conflicting findings described above. However, the recent finding that specific viral-mediated down-regulation of $A l k$, as well as its pharmacological inhibition, reduces drinking (Dutton et al. 2017) and strengthens the possibility that ALK plays a role in the "GO pathways." Finally, because of the paucity of information from the studies assessing the effects of IGF-1 manipulations on alcohol-related behaviors, it is not possible yet to determine the role of this growth factor in the regulation of alcohol intake.

It is interesting to note that all the growth factors we mention here activate receptor tyrosine kinases, which in turn activate similar downstream intracellular signaling pathways (e.g., ERK1/2, PI3K, and PLC $\gamma$ ). Although it could be expected that activation of similar signaling pathways would yield similar phenotypes, the data reviewed here shows diverse outcomes, suggesting that additional factors determine the effects of the growth factor on alcohol-drinking behaviors. For example, activation of the MAPK pathway in the VTA by GDNF (Carnicella et al. 2008) or in the DLS by BDNF (Jeanblanc et al. 2013) reduces alcohol intake. In contrast, activation of the PI3K-AKT pathway in the NAc (Neasta et al. 2011), or in the DMS by FGF2 (Even-Chen and Barak 2019b), mediates increased alcohol consumption. As we previously suggested (Ron and Barak
2016), it is most likely that the phenotype is determined by complex interaction between the site of action and the specific signaling pathway that mediates the behavioral effects.

Finally, the translational implications of findings from animal studies for AUD in humans is a critical question. While we do not systematically review here studies that implicate alteration in growth factors in human patients, we mentioned several findings that clearly link fluctuations in the growth factors to the severity of AUD. We also touched upon the possibility that genetic variations in growth factors in humans is a predisposition factor for the development of the disease. In addition, drugs that interfere with or activate some of the growth factor systems have been reported to yield promising outcomes in animal models. Therefore, further research is required to fully understand the translational value of these reports, including translation of the findings in animal models to clinical trials in human patients.

\section{ACKNOWLEDGMENTS}

Supported by the U.S.-Israel Binational Science Foundation BSF 2017022 (S.B.), the National Institute of Psychobiology in Israel (S.B), and the National Institute of Alcohol Abuse and Alcoholism R37AA01684 (D.R.). The authors declare no competing financial interests.

\section{REFERENCES}

Abrahao KP, Salinas AG, Lovinger DM. 2017. Alcohol and the brain: neuronal molecular targets, synapses, and circuits. Neuron 96: 1223-1238. doi:10.1016/j.neuron.2017 .10 .032

Ahmadiantehrani S, Barak S, Ron D. 2014. GDNF is a novel ethanol-responsive gene in the VTA: implications for the development and persistence of excessive drinking. Addict Biol 19: 623-633. doi:10.1111/adb.12028

Airaksinen MS, Saarma M. 2002. The GDNF family: signalling, biological functions and therapeutic value. Nat Rev Neurosci 3: 383-394. doi:10.1038/nrn812

Airavaara M, Planken A, Gäddnäs H, Piepponen TP, Saarma M, Ahtee L. 2004. Increased extracellular dopamine concentrations and FosB $/ \Delta$ FosB expression in striatal brain areas of heterozygous GDNF knockout mice. Eur J Neurosci 20: 2336-2344. doi:10.1111/j.1460-9568.2004.03700.x

Alele PE, Devaud LL. 2013. Expression of cFos and brainderived neurotrophic factor in cortex and hippocampus 
of ethanol-withdrawn male and female rats. J Pharmacol Pharmacother 4: 265-274. doi:10.4103/0976-500X .119712

Alguacil LF, Herradón G. 2015. Midkine and pleiotrophin in the treatment of neurodegenerative diseases and drug addiction. Recent Pat CNS Drug Discov 10: 28-33. doi:10 .2174/1574889810666150326103916

Allard JB, Duan C. 2018. IGF-binding proteins: why do they exist and why are there so many? Front Endocrinol (Lausanne) 9: 117-117. doi:10.3389/fendo.2018.00117

Andero R, Choi DC, Ressler KJ. 2014. BDNF-TrkB receptor regulation of distributed adult neural plasticity, memory formation, and psychiatric disorders. Prog Mol Biol Transl Sci 122: 169-192. doi:10.1016/B978-0-12-4201 70-5.00006-4

Autry AE, Monteggia LM. 2012. Brain-derived neurotrophic factor and neuropsychiatric disorders. Pharmacol Rev 64: 238-258. doi:10.1124/pr.111.005108

Bahi A, Dreyer J-L. 2013. Striatal modulation of BDNF expression using microRNA124a-expressing lentiviral vectors impairs ethanol-induced conditioned-place preference and voluntary alcohol consumption. Eur J Neurosci 38: 2328-2337. doi:10.1111/ejn.12228

Bailey CP, O'Callaghan MJ, Croft AP, Manley SJ, Little HJ. 2001. Alterations in mesolimbic dopamine function during the abstinence period following chronic ethanol consumption. Neuropharmacology 41: 989-999. doi:10.1016/ S0028-3908(01)00146-0

Barak S, Ahmadiantehrani S, Kharazia V, Ron D. 2011a Positive autoregulation of GDNF levels in the ventral tegmental area mediates long-lasting inhibition of excessive alcohol consumption. Transl Psychiatry 1: e60. doi:10 .1038/tp.2011.57

Barak S, Carnicella S, Yowell QV, Ron D. 2011b. Glial cell line-derived neurotrophic factor reverses alcohol-induced allostasis of the mesolimbic dopaminergic system: implications for alcohol reward and seeking. J Neurosci 31: 9885-9894. doi:10.1523/jneurosci.1750-11.2011

Barak S, Wang J, Ahmadiantehrani S, Ben Hamida S, Kells AP, Forsayeth J, Bankiewicz KS, Ron D. 2015. Glial cell line-derived neurotrophic factor (GDNF) is an endogenous protector in the mesolimbic system against excessive alcohol consumption and relapse. Addict Biol 20: 629642. doi:10.1111/adb.12152

Barak S, Ahmadiantehrani S, Logrip ML, Ron D. 2019. GDNF and alcohol use disorder. Addict Biol 24: 335343. doi:10.1111/adb.12628

Barde YA. 1994. Neurotrophins: a family of proteins supporting the survival of neurons. Prog Clin Biol Res 390: 45-56.

Barde YA, Edgar D, Thoenen H. 1982. Purification of a new neurotrophic factor from mammalian brain. $E M B O J \mathbf{~ 1 :}$ 549-553. doi:10.1002/j.1460-2075.1982.tb01207.x

Barroso-Chinea P, Cruz-Muros I, Aymerich MS, RodríguezDíaz M, Afonso-Oramas D, Lanciego JL, González-Hernández T. 2005. Striatal expression of GDNF and differential vulnerability of midbrain dopaminergic cells. Eur $J$ Neurosci 21: 1815-1827. doi:10.1111/j.1460-9568.2005 .04024.x

Bartel DP. 2004. MicroRNAs: genomics, biogenesis, mechanism, and function. Cell 116: 281-297. doi:10.1016/ S0092-8674(04)00045-5
Berglind WJ, See RE, Fuchs RA, Ghee SM, Whitfield TW Jr, Miller SW, McGinty JF. 2007. A BDNF infusion into the medial prefrontal cortex suppresses cocaine seeking in rats. Eur J Neurosci 26: 757-766. doi:10.1111/j.14609568.2007.05692.x

Berglind WJ, Whitfield TW Jr, LaLumiere RT, Kalivas PW, McGinty JF. 2009. A single intra-PFC infusion of BDNF prevents cocaine-induced alterations in extracellular glutamate within the nucleus accumbens. J Neurosci 29: 3715-3719. doi:10.1523/jneurosci.5457-08.2009

Bespalov MM, Saarma M. 2007. GDNF family receptor complexes are emerging drug targets. Trends Pharmacol Sci 28: 68-74. doi:10.1016/j.tips.2006.12.005

Bespalov MM, Sidorova YA, Tumova S, Ahonen-Bishopp A, Magalhães AC, Kulesskiy E, Paveliev M, Rivera C, Rauvala H, Saarma M. 2011. Heparan sulfate proteoglycan syndecan-3 is a novel receptor for GDNF, neurturin, and artemin. J Cell Biol 192: 153-169. doi:10.1083/jcb.201009136

Breese CR, Ingram RL, Sonntag WE. 1991. Influence of age and long-term dietary restriction on plasma insulin-like growth factor-1 (IGF-1), IGF-1 gene expression, and IGF1 binding proteins. J Gerontol 46: B180-B187. doi:10 .1093/geronj/46.5.B180

Breese CR, D'Costa A, Sonntag WE. 1994. Effect of in utero ethanol exposure on the postnatal ontogeny of insulinlike growth factor-1, and type-1 and type-2 insulin-like growth factor receptors in the rat brain. Neuroscience 63: 579-589. doi:10.1016/0306-4522(94)90551-7

Briones TL, Woods J. 2013. Chronic binge-like alcohol consumption in adolescence causes depression-like symptoms possibly mediated by the effects of BDNF on neurogenesis. Neuroscience 254: 324-334. doi:10.1016/j.neu roscience.2013.09.031

Buckley PF, Mahadik S, Pillai A, Terry A Jr. 2007. Neurotrophins and schizophrenia. Schizophr Res 94: 1-11. doi:10.1016/j.schres.2007.01.025

Carnicella S, Ron D. 2009. GDNF-a potential target to treat addiction. Pharmacol Ther 122: 9-18. doi:10.1016/j pharmthera.2008.12.001

Carnicella S, Kharazia V, Jeanblanc J, Janak PH, Ron D. 2008. GDNF is a fast-acting potent inhibitor of alcohol consumption and relapse. Proc Natl Acad Sci 105: 81148119. doi:10.1073/pnas.0711755105

Carnicella S, Amamoto R, Ron D. 2009a. Excessive alcohol consumption is blocked by glial cell line-derived neurotrophic factor. Alcohol 43: 35-43. doi:10.1016/j.alcohol .2008.12.001

Carnicella S, Ahmadiantehrani S, Janak PH, Ron D. 2009b. GDNF is an endogenous negative regulator of ethanolmediated reward and of ethanol consumption after a period of abstinence. Alcohol Clin Exp Res 33: 1012-1024 doi:10.1111/j.1530-0277.2009.00922.x

Carnicella S, Ahmadiantehrani S, He D-Y, Nielsen CK, Bartlett SE, Janak PH, Ron D. 2009c. Cabergoline decreases alcohol drinking and seeking behaviors via glial cell linederived neurotrophic factor. Biol Psychiatry 66: 146-153. doi:10.1016/j.biopsych.2008.12.022

Carnicella S, Ron D, Barak S. 2014. Intermittent ethanol access schedule in rats as a preclinical model of alcohol abuse. Alcohol 48: 243-252. doi:10.1016/j.alcohol.2014 .01 .006 
M. Liran et al.

Carvalho AF, Heilig M, Perez A, Probst C, Rehm J. 2019. Alcohol use disorders. Lancet 394: 781-792. doi:10.1016/ S0140-6736(19)31775-1

Castrén E. 2004. Neurotrophins as mediators of drug effects on mood, addiction, and neuroprotection. Mol Neurobiol 29: 289-302. doi:10.1385/MN:29:3:289

Castrén E. 2014. Neurotrophins and psychiatric disorders. Handb Exp Pharmacol 220: 461-479. doi:10.1007/978-3642-45106-5_17

Chen Z-Y, Patel PD, Sant G, Meng CX, Teng KK, Hempstead BL, Lee FS. 2004. Variant brain-derived neurotrophic factor (BDNF) (Met66) alters the intracellular trafficking and activity-dependent secretion of wild-type BDNF in neurosecretory cells and cortical neurons. J Neurosci 24: 4401-4411. doi:10.1523/jneurosci.0348-04.2004

Chen H, He D, Lasek AW. 2017. Midkine in the mouse ventral tegmental area limits ethanol intake and $\mathrm{Ccl} 2$ gene expression. Genes Brain Behav 16: 699-708. doi:10 $.1111 / \mathrm{gbb} .12384$

Chlebova K, Bryja V, Dvorak P, Kozubik A, Wilcox WR, Krejci P. 2009. High molecular weight FGF2: the biology of a nuclear growth factor. Cell Mol Life Sci 66: 225-235. doi:10.1007/s00018-008-8440-4

Chul BL, Choi I-G, Kim Y-K, Ham B-J, Yang B-H, Roh S, Choi J, Lee J-S, Oh D-Y, Chai Y-G. 2009. Relation between plasma brain-derived neurotrophic factor and nerve growth factor in the male patients with alcohol dependence. Alcohol 43: 265-269. doi:10.1016/j.alcohol.2009 .04 .003

Claus P, Werner S, Timmer M, Grothe C. 2004. Expression of the fibroblast growth factor-2 isoforms and the FGF receptor 1-4 transcripts in the rat model system of Parkinson's disease. Neurosci Lett 360: 117-120. doi:10 .1016/j.neulet.2004.01.046

Clemmons DR. 2004. The relative roles of growth hormone and IGF-1 in controlling insulin sensitivity. J Clin Invest 113: 25-27. doi:10.1172/JCI20660

Cohen AC, Tong M, Wands JR, de la Monte SM. 2007. Insulin and insulin-like growth factor resistance with neurodegeneration in an adult chronic ethanol exposure model. Alcohol Clin Exp Res 31: 1558-1573. doi:10 .1111/j.1530-0277.2007.00450.x

Costa M-A, Girard M, Dalmay F, Malauzat D. 2011. Brainderived neurotrophic factor serum levels in alcoholdependent subjects 6 months after alcohol withdrawal. Alcohol Clin Exp Res 35: 1966-1973. doi:10.1111/j 1530-0277.2011.01548.x

Cowansage KK, LeDoux JE, Monfils M-H. 2010. Brain-derived neurotrophic factor: a dynamic gatekeeper of neural plasticity. Curr Mol Pharmacol 3: 12-29. doi:10.2174/ 1874467211003010012

Cummings BJ, Su JH, Cotman CW. 1993. Neuritic involvement within bFGF immunopositive plaques of $\mathrm{Alz}$ heimer's disease. Exp Neurol 124: 315-325. doi:10.1006/ exnr.1993.1202

Darcq E, Warnault V, Phamluong K, Besserer GM, Liu F, Ron D. 2015. MicroRNA-30a-5p in the prefrontal cortex controls the transition from moderate to excessive alcohol consumption. Mol Psychiatry 20: 1219-1231. doi:10 $.1038 / \mathrm{mp} .2014 .122$

Darcq E, Morisot N, Phamluong K, Warnault V, Jeanblanc J, Longo FM, Massa SM, Ron D. 2016. The neurotrophic factor receptor p75 in the rat dorsolateral striatum drives excessive alcohol drinking. J Neurosci 36: 10116-10127. doi:10.1523/jneurosci.4597-14.2016

Davies AM, Thoenen H, Barde Y-A. 1986. Different factors from the central nervous system and periphery regulate the survival of sensory neurones. Nature 319: 497-499. doi:10.1038/319497a0

Delafontaine P, Song Y-H, Li Y. 2004. Expression, regulation, and function of IGF-1, IGF-1R, and IGF-1 binding proteins in blood vessels. Arterioscler Thromb Vasc Biol 24: 435-444. doi:10.1161/01.ATV.0000105902.89459.09

de la Monte SM, Xu XJ, Wands JR. 2005. Ethanol inhibits insulin expression and actions in the developing brain Cell Mol Life Sci 62: 1131-1145. doi:10.1007/s00018005-4571-z

Diana M, Pistis M, Carboni S, Gessa GL, Rossetti ZL. 1993. Profound decrement of mesolimbic dopaminergic neuronal activity during ethanol withdrawal syndrome in rats: electrophysiological and biochemical evidence. Proc Natl Acad Sci 90: 7966-7969. doi:10.1073/pnas.90.17.7966

Dole VP, Gentry RT. 1984. Toward an analogue of alcoholism in mice: scale factors in the model. Proc Natl Acad Sci 81: 3543-3546. doi:10.1073/pnas.81.11.3543

Dono R, Texido G, Dussel R, Ehmke H, Zeller R. 1998. Impaired cerebral cortex development and blood pressure regulation in FGF-2-deficient mice. EMBO J 17: 4213 4225. doi:10.1093/emboj/17.15.4213

Durbec P, Marcos-Gutierrez CV, Kilkenny C, Grigoriou M, Wartiowaara K, Suvanto P, Smith D, Ponder B, Costantini F, Saarma M, et al. 1996. GDNF signalling through the Ret receptor tyrosine kinase. Nature 381: 789-793. doi:10 $.1038 / 381789 \mathrm{a} 0$

Dutton JW III, Chen H, You C, Brodie MS, Lasek AW. 2017. Anaplastic lymphoma kinase regulates binge-like drinking and dopamine receptor sensitivity in the ventral tegmental area. Addict Biol 22: 665-678. doi:10.1111/adb .12358

Egan MF, Kojima M, Callicott JH, Goldberg TE, Kolachana BS, Bertolino A, Zaitsev E, Gold B, Goldman D, Dean M, et al. 2003. The BDNF val66met polymorphism affects activity-dependent secretion of BDNF and human memory and hippocampal function. Cell 112: 257-269. doi:10 1016/S0092-8674(03)00035-7

Elsayed M, Banasr M, Duric V, Fournier NM, Licznerski P, Duman RS. 2012. Antidepressant effects of fibroblast growth factor-2 in behavioral and cellular models of depression. Biol Psychiatry 72: 258-265. doi:10.1016/j .biopsych.2012.03.003

Eren-Koçak E, Turner CA, Watson SJ, Akil H. 2011. Shorthairpin RNA silencing of endogenous fibroblast growth factor 2 in rat hippocampus increases anxiety behavior. Biol Psychiatry 69: 534-540. doi:10.1016/j.biopsych.2010 .11 .020

Eswarakumar VP, Lax I, Schlessinger J. 2005. Cellular signaling by fibroblast growth factor receptors. Cytokine Growth Factor Rev 16: 139-149. doi:10.1016/j.cytogfr 2005.01.001

Even-Chen O, Barak S. 2019a. The role of fibroblast growth factor 2 in drug addiction. Eur J Neurosci 50: 2552-2561. doi:10.1111/ejn.14133

Even-Chen O, Barak S. 2019b. Inhibition of FGF receptor-1 suppresses alcohol consumption: role of PI3 kinase sig- 
naling in dorsomedial striatum. $J$ Neurosci 39: 79477957. doi:10.1523/jneurosci.0805-19.2019

Even-Chen O, Sadot-Sogrin Y, Shaham O, Barak S. 2017. Fibroblast growth factor 2 in the dorsomedial striatum is a novel positive regulator of alcohol consumption. $J$ Neurosci 37: 8742-8754. doi:10.1523/jneurosci.0890-17 .2017

Everitt BJ, Robbins TW. 2013. From the ventral to the dorsal striatum: devolving views of their roles in drug addiction. Neurosci Biobehav Rev 37: 1946-1954. doi:10.1016/j neubiorev.2013.02.010

Ewenczyk A, Ziplow J, Tong M, Le T, de la Monte SM. 2012. Sustained impairments in brain insulin/IGF signaling in adolescent rats subjected to binge alcohol exposure during development. J Clin Exp Pathol 2: 106. doi:10.4172/ 2161-0681.1000106

Feltenstein MW, See RE. 2013. Systems level neuroplasticity in drug addiction. Cold Spring Harb Perspect Med 3: a011916. doi:10.1101/cshperspect.a011916

Fernández-Calle R, Gramage E, Zapico JM, de Pascual-Teresa B, Ramos A, Herradón G. 2019. Inhibition of RPTP $\beta$ / $\zeta$ blocks ethanol-induced conditioned place preference in pleiotrophin knockout mice. Behav Brain Res 369: 111933. doi:10.1016/j.bbr.2019.111933

Flatscher-Bader T, Wilce PA. 2006. Chronic smoking and alcoholism change expression of selective genes in the human prefrontal cortex. Alcohol Clin Exp Res 30: 908915. doi:10.1111/j.1530-0277.2006.00106.x

Flatscher-Bader T, Wilce PA. 2008. Impact of alcohol abuse on protein expression of midkine and excitatory amino acid transporter 1 in the human prefrontal cortex. Alcohol Clin Exp Res 32: 1849-1858. doi:10.1111/j.1530-0277 .2008.00754.x

Flatscher-Bader T, van der Brug M, Hwang JW, Gochee PA, Matsumoto I, Niwa S, Wilce PA. 2005. Alcohol-responsive genes in the frontal cortex and nucleus accumbens of human alcoholics. J Neurochem 93: 359-370. doi:10 $.1111 / \mathrm{j} .1471-4159.2004 .03021 . x$

Ford-Perriss M, Abud H, Murphy M. 2001. Fibroblast growth factors in the developing central nervous system. Clin Exp Pharmacol Physiol 28: 493-503. doi:10.1046/j .1440-1681.2001.03477.x

Förthmann B, Grothe C, Claus P. 2015. A nuclear odyssey: fibroblast growth factor-2 (FGF-2) as a regulator of nuclear homeostasis in the nervous system. Cell Mol Life Sci 72: 1651-1662. doi:10.1007/s00018-014-1818-6

Fumagalli F, Bedogni F, Slotkin TA, Racagni G, Riva MA. 2005. Prenatal stress elicits regionally selective changes in basal FGF-2 gene expression in adulthood and alters the adult response to acute or chronic stress. Neurobiol Dis 20: 731-737. doi:10.1016/j.nbd.2005.05.005

García-Marchena N, Silva-Peña D, Martín-Velasco AI, Villanúa MÁ, Araos P, Pedraz M, Maza-Quiroga R, RomeroSanchiz P, Rubio G, Castilla-Ortega E, et al. 2017. Decreased plasma concentrations of BDNF and IGF-1 in abstinent patients with alcohol use disorders. PLoS One 12: e0187634. doi:10.1371/journal.pone.0187634

Ghitza UE, Zhai H, Wu P, Airavaara M, Shaham Y, Lu L. 2010. Role of BDNF and GDNF in drug reward and relapse: a review. Neurosci Biobehav Rev 35: 157-171. doi:10 $.1016 /$ j.neubiorev.2009.11.009
Glazner GW, Mu X, Springer JE. 1998. Localization of glial cell line-derived neurotrophic factor receptor $\alpha$ and c-ret mRNA in rat central nervous system. J Comp Neurol 391: 42-49. doi:10.1002/(SICI)1096-9861(19980202)391 :1<42::AID-CNE4>3.0.CO;2-R

Gonzalez AM, Berry M, Maher PA, Logan A, Baird A. 1995. A comprehensive analysis of the distribution of FGF-2 and FGFR1 in the rat brain. Brain Res 701: 201-226. doi:10.1016/0006-8993(95)01002-X

Graham BM, Richardson R. 2011. Memory of fearful events: the role of fibroblast growth factor- 2 in fear acquisition and extinction. Neuroscience 189: 156-169. doi:10.1016/j .neuroscience.2011.05.041

Graham DL, Edwards S, Bachtell RK, DiLeone RJ, Rios M, Self DW. 2007. Dynamic BDNF activity in nucleus accumbens with cocaine use increases self-administration and relapse. Nat Neurosci 10: 1029-1037. doi:10.1038/ nn1929

Graham DL, Krishnan V, Larson EB, Graham A, Edwards S, Bachtell RK, Simmons D, Gent LM, Berton O, Bolanos CA, et al. 2009. Tropomyosin-related kinase B in the mesolimbic dopamine system: region-specific effects on cocaine reward. Biol Psychiatry 65: 696-701. doi:10.1016/j .biopsych.2008.09.032

Grant BF, Chou SP, Saha TD, Pickering RP, Kerridge BT, Ruan WJ, Huang B, Jung J, Zhang H, Fan A, et al. 2017. Prevalence of 12-month alcohol use, high-risk drinking, and DSM-IV alcohol use disorder in the United States, 2001-2002 to 2012-2013: results from the National Epidemiologic Survey on Alcohol and Related Conditions. JAMA Psychiatry 74: 911-923. doi:10.1001/jamapsychia try.2017.2161

Griffin WC III, Boger HA, Granholm AC, Middaugh LD. 2006. Partial deletion of glial cell line-derived neurotrophic factor (GDNF) in mice: effects on sucrose reward and striatal GDNF concentrations. Brain Res 1068: 257-260. doi:10.1016/j.brainres.2005.10.080

Grondin R, Littrell OM, Zhang Z, Ai Y, Huettl P, Pomerleau F, Quintero JE, Andersen AH, Stenslik MJ, Bradley LH, et al. 2019. GDNF revisited: a novel mammalian cell-derived variant form of GDNF increases dopamine turnover and improves brain biodistribution. Neuropharmacology 147: 28-36. doi:10.1016/j.neuropharm.2018.05.014

Hafenbreidel M, Twining RC, Rafa Todd C, Mueller D. 2015. Blocking infralimbic basic fibroblast growth factor (bFGF or FGF2) facilitates extinction of drug seeking after cocaine self-administration. Neuropsychopharmacology 40: 2907-2915. doi:10.1038/npp.2015.144

Hallberg B, Palmer RH. 2013. Mechanistic insight into ALK receptor tyrosine kinase in human cancer biology. Nat Rev Cancer 13: 685-700. doi:10.1038/nrc3580

Hallberg B, Palmer RH. 2016. The role of the ALK receptor in cancer biology. Ann Oncol 27: iii4-iii15. doi:10.1093/ annonc/mdw301

Haun HL, Griffin WC, Lopez MF, Solomon MG, Mulholland PJ, Woodward JJ, McGinty JF, Ron D, Becker HC 2018. Increasing brain-derived neurotrophic factor (BDNF) in medial prefrontal cortex selectively reduces excessive drinking in ethanol dependent mice. Neuropharmacology 140: 35-42. doi:10.1016/j.neuropharm .2018 .07 .031 
M. Liran et al.

He D-Y, Ron D. 2006. Autoregulation of glial cell line-derived neurotrophic factor expression: implications for the long-lasting actions of the anti-addiction drug, Ibogaine. FASEB J 20: 2420-2422. doi:10.1096/fj.06-6394fje

He D-Y, Neasta J, Ron D. 2010. Epigenetic regulation of $B D N F$ expression via the scaffolding protein RACK1. $J$ Biol Chem 285: 19043-19050. doi:10.1074/jbc.M110 .100693

Hearing MC, Miller SW, See RE, McGinty JF. 2008. Relapse to cocaine seeking increases activity-regulated gene expression differentially in the prefrontal cortex of abstinent rats. Psychopharmacology (Berl) 198: 77-91. doi:10.1007/ s00213-008-1090-2

Heberlein A, Muschler M, Wilhelm J, Frieling H, Lenz B, Gröschl M, Kornhuber J, Bleich S, Hillemacher T. 2010. BDNF and GDNF serum levels in alcohol-dependent patients during withdrawal. Prog Neuro-Psychopharmacol Biol Psychiatry 34: 1060-1064. doi:10.1016/j.pnpbp.2010 .05 .025

Heberlein A, Büscher P, Schuster R, Kleimann A, Lichtinghagen R, Rhein M, Kornhuber J, Bleich S, Frieling H, Hillemacher T. 2015. Do changes in the BDNF promoter methylation indicate the risk of alcohol relapse? Eur Neuropsychopharmacol 25: 1892-1897. doi:10.1016/j .euroneuro.2015.08.018

Hensler JG, Ladenheim EE, Lyons WE. 2003. Ethanol consumption and serotonin-1A $\left(5-\mathrm{HT}_{1 \mathrm{~A}}\right)$ receptor function in heterozygous BDNF $(+/-)$ mice. J Neurochem 85: 1139-1147. doi:10.1046/j.1471-4159.2003.01748.x

Herradón G, Pérez-García C. 2014. Targeting midkine and pleiotrophin signalling pathways in addiction and neurodegenerative disorders: recent progress and perspectives. Br J Pharmacol 171: 837-848. doi:10.1111/bph.12312

Hofer M, Pagliusi SR, Hohn A, Leibrock J, Barde YA. 1990 Regional distribution of brain-derived neurotrophic factor mRNA in the adult mouse brain. EMBO J 9: 24592464. doi:10.1002/j.1460-2075.1990.tb07423.x

Hogarth L, Balleine BW, Corbit LH, Killcross S. 2013. Associative learning mechanisms underpinning the transition from recreational drug use to addiction. Ann NY Acad Sci 1282: 12-24. doi:10.1111/j.1749-6632.2012.06768.x

Horger BA, Iyasere CA, Berhow MT, Messer CJ, Nestler EJ, Taylor JR. 1999. Enhancement of locomotor activity and conditioned reward to cocaine by brain-derived neurotrophic factor. J Neurosci 19: 4110-4122. doi:10.1523/ jneurosci.19-10-04110.1999

Huang EJ, Reichardt LF. 2003. Trk receptors: roles in neuronal signal transduction. Annu Rev Biochem 72: 609642. doi:10.1146/annurev.biochem.72.121801.161629

Huang M-C, Chen C-H, Chen C-H, Liu S-C, Ho C-J, Shen W-W, Leu S-J. 2008. Alterations of serum brain-derived neurotrophic factor levels in early alcohol withdrawal. Alcohol Alcohol 43: 241-245. doi:10.1093/alcalc/agm172

Ibáñez CF, Andressoo J-O. 2017. Biology of GDNF and its receptors-relevance for disorders of the central nervous system. Neurobiol Dis 97: 80-89. doi:10.1016/j.nbd.2016 .01 .021

Iwahara T, Fujimoto J, Wen D, Cupples R, Bucay N, Arakawa T, Mori S, Ratzkin B, Yamamoto T. 1997. Molecular characterization of ALK, a receptor tyrosine kinase expressed specifically in the nervous system. Oncogene 14: 439-449. doi:10.1038/sj.onc.1200849
Jeanblanc J, He DY, McGough NN, Logrip ML, Phamluong $\mathrm{K}$, Janak PH, Ron D. 2006. The dopamine D3 receptor is part of a homeostatic pathway regulating ethanol consumption. J Neurosci 26: 1457-1464. doi:10.1523/jneuro sci.3786-05.2006

Jeanblanc J, He D-Y, Carnicella S, Kharazia V, Janak PH, Ron D. 2009. Endogenous BDNF in the dorsolateral striatum gates alcohol drinking. J Neurosci 29: 13494-13502. doi:10.1523/jneurosci.2243-09.2009

Jeanblanc J, Logrip ML, Janak PH, Ron D. 2013. BDNFmediated regulation of ethanol consumption requires the activation of the MAP kinase pathway and protein synthesis. Eur J Neurosci 37: 607-612. doi:10.1111/ejn .12067

Jing S, Wen D, Yu Y, Holst PL, Luo Y, Fang M, Tamir R, Antonio L, Hu Z, Cupples R, et al. 1996. GDNF-induced activation of the ret protein tyrosine kinase is mediated by GDNFR- $\alpha$, a novel receptor for GDNF. Cell 85: 11131124. doi:10.1016/S0092-8674(00)81311-2

Joe K-H, Kim Y-K, Kim T-S, Roh S-W, Choi S-W, Kim Y-B, Lee H-J, Kim D-J. 2007. Decreased plasma brain-derived neurotrophic factor levels in patients with alcohol dependence. Alcohol Clin Exp Res 31: 1833-1838. doi:10.1111/j 1530-0277.2007.00507.x

Junnila RK, List EO, Berryman DE, Murrey JW, Kopchick JJ. 2013. The GH/IGF-1 axis in ageing and longevity. Nat Rev Endocrinol 9: 366-376. doi:10.1038/nrendo.2013.67

Karege F, Schwald M, Cisse M. 2002. Postnatal developmental profile of brain-derived neurotrophic factor in rat brain and platelets. Neurosci Lett 328: 261-264. doi:10.1016/ S0304-3940(02)00529-3

Kiyota T, Ingraham KL, Jacobsen MT, Xiong H, Ikezu T. 2011. FGF2 gene transfer restores hippocampal functions in mouse models of Alzheimer's disease and has therapeutic implications for neurocognitive disorders. Proc Natl Acad Sci 108: E1339-E1348. doi:10.1073/pnas .1102349108

Klein R, Martin-Zanca D, Barbacid M, Parada LF. 1990. Expression of the tyrosine kinase receptor gene trkB is confined to the murine embryonic and adult nervous system. Development 109: 845-850.

Klein AB, Williamson R, Santini MA, Clemmensen C, Ettrup A, Rios M, Knudsen GM, Aznar S. 2011. Blood BDNF concentrations reflect brain-tissue BDNF levels across species. Int J Neuropsychopharmacol 14: 347353. doi:10.1017/S1461145710000738

Klejbor I, Myers JM, Hausknecht K, Corso TD, Gambino AS, Morys J, Maher PA, Hard R, Richards J, Stachowiak EK, et al. 2006. Fibroblast growth factor receptor signaling affects development and function of dopamine neuronsinhibition results in a schizophrenia-like syndrome in transgenic mice. J Neurochem 97: 1243-1258. doi:10 $.1111 /$ j.1471-4159.2006.03754.x

Koo JW, Chaudhury D, Han M-H, Nestler EJ. 2019. Role of mesolimbic brain-derived neurotrophic factor in depression. Biol Psychiatry 86: 738-748. doi:10.1016/j.biopsych .2019 .05 .020

Koob GF, Le Moal M. 2001. Drug addiction, dysregulation of reward, and allostasis. Neuropsychopharmacology 24: 97 129. doi:10.1016/S0893-133X(00)00195-0

Kordower JH, Emborg ME, Bloch J, Ma SY, Chu Y, Leventhal L, McBride J, Chen EY, Palfi S, Roitberg BZ, et al. 2000. 
Neurodegeneration prevented by lentiviral vector delivery of GDNF in primate models of Parkinson's disease. Science 290: 767-773. doi:10.1126/science.290.5492.767

Koskela M, Bäck S, Võikar V, Richie CT, Domanskyi A, Harvey BK, Airavaara M. 2017. Update of neurotrophic factors in neurobiology of addiction and future directions. Neurobiol Dis 97: 189-200. doi:10.1016/j.nbd.2016.05 .010

Kraemer BR, Yoon SO, Carter BD. 2014. The biological functions and signaling mechanisms of the p75 neurotrophin receptor. Handb Exp Pharmacol 220: 121-164. doi:10.1007/978-3-642-45106-5_6

Kumar A, Kopra J, Varendi K, Porokuokka LL, Panhelainen A, Kuure S, Marshall P, Karalija N, Härma M-A, Vilenius C, et al. 2015. GDNF overexpression from the native locus reveals its role in the nigrostriatal dopaminergic system function. PLoS Genet 11: e1005710. doi:10.1371/journal .pgen. 1005710

Laron Z. 2001. Insulin-like growth factor 1 (IGF-1): a growth hormone. Mol Pathol 54: 311-316. doi:10.1136/mp.54.5 .311

Lasek AW, Lim J, Kliethermes CL, Berger KH, Joslyn G, Brush G, Xue L, Robertson M, Moore MS, Vranizan K, et al. 2011. An evolutionary conserved role for anaplastic lymphoma kinase in behavioral responses to ethanol. PLoS One 6: e22636. doi:10.1371/journal.pone.0022636

Leggio L, Ferrulli A, Malandrino N, Miceli A, Capristo E, Gasbarrini G, Addolorato G. 2008. Insulin but not insulin growth factor-1 correlates with craving in currently drinking alcohol-dependent patients. Alcohol Clin Exp Res 32: 450-458. doi:10.1111/j.1530-0277.2007.00589.x

Lhullier AC, Moreira FP, da Silva RA, Marques MB, Bittencourt G, Pinheiro RT, Souza LD, Portela LV, Lara DR, Jansen K, et al. 2015. Increased serum neurotrophin levels related to alcohol use disorder in a young population sample. Alcohol Clin Exp Res 39: 30-35. doi:10.1111/ acer. 12592

Li TK, Lumeng L, McBride WJ, Murphy JM. 1987. Rodent lines selected for factors affecting alcohol consumption. Alcohol Alcohol Suppl 1: 91-96.

Lin LF, Doherty DH, Lile JD, Bektesh S, Collins F. 1993. GDNF: a glial cell line-derived neurotrophic factor for midbrain dopaminergic neurons. Science 260: 11301132. doi:10.1126/science. 8493557

Logrip ML, Janak PH, Ron D. 2008. Dynorphin is a downstream effector of striatal BDNF regulation of ethanol intake. FASEB J 22: 2393-2404. doi:10.1096/fj.07-099135

Logrip ML, Janak PH, Ron D. 2009. Escalating ethanol intake is associated with altered corticostriatal BDNF expression. J Neurochem 109: 1459-1468. doi:10.1111/j .1471-4159.2009.06073.x

Logrip ML, Barak S, Warnault V, Ron D. 2015. Corticostriatal BDNF and alcohol addiction. Brain Res 1628: 60-67. doi:10.1016/j.brainres.2015.03.025

Lu L, Dempsey J, Liu SY, Bossert JM, Shaham Y. 2004. A single infusion of brain-derived neurotrophic factor into the ventral tegmental area induces long-lasting potentiation of cocaine seeking after withdrawal. J Neurosci 24: 1604-1611. doi:10.1523/jneurosci.5124-03.2004

Lu Y, Christian K, Lu B. 2008. BDNF: a key regulator for protein synthesis-dependent LTP and long-term memo- ry? Neurobiol Learn Memory 89: 312-323. doi:10.1016/j .nlm.2007.08.018

Lu B, Nagappan G, Lu Y. 2014. BDNF and synaptic plasticity, cognitive function, and dysfunction. Handb Exp Pharmacol 220: 223-250. doi:10.1007/978-3-642-45106-5_9

Lüscher C, Malenka RC. 2011. Drug-evoked synaptic plasticity in addiction: from molecular changes to circuit remodeling. Neuron 69: 650-663. doi:10.1016/j.neuron .2011 .01 .017

Mallei A, Shi B, Mocchetti I. 2002. Antidepressant treatments induce the expression of basic fibroblast growth factor in cortical and hippocampal neurons. Mol Pharmacol 61: 1017-1024. doi:10.1124/mol.61.5.1017

Mangieri RA, Maier EY, Buske TR, Lasek AW, Morrisett RA. 2017. Anaplastic lymphoma kinase is a regulator of alcohol consumption and excitatory synaptic plasticity in the nucleus accumbens shell. Front Pharmacol 8: 533. doi:10 .3389/fphar.2017.00533

Maragnoli ME, Fumagalli F, Gennarelli M, Racagni G, Riva MA. 2004. Fluoxetine and olanzapine have synergistic effects in the modulation of fibroblast growth factor 2 expression within the rat brain. Biol Psychiatry 55: 1095-1102. doi:10.1016/j.biopsych.2004.02.003

Matsushita S, Kimura M, Miyakawa T, Yoshino A, Murayama M, Masaki T, Higuchi S. 2004. Association study of brain-derived neurotrophic factor gene polymorphism and alcoholism. Alcohol Clin Exp Res 28: 1609-1612. doi:10.1097/01.ALC.0000145697.81741.D2

Maynard ME, Barton EA, Robinson CR, Wooden JI, Leasure JL. 2018. Sex differences in hippocampal damage, cognitive impairment, and trophic factor expression in an animal model of an alcohol use disorder. Brain Struct Funct 223: 195-210. doi:10.1007/s00429-017-1482-3

McGinnis JM, Foege WH. 1999. Mortality and morbidity attributable to use of addictive substances in the United States. Proc Assoc Am Physicians 111: 109-118. doi:10 $.1046 / j .1525-1381.1999 .09256 . x$

McGough NN, He DY, Logrip ML, Jeanblanc J, Phamluong K, Luong K, Kharazia V, Janak PH, Ron D. 2004. RACK1 and brain-derived neurotrophic factor: a homeostatic pathway that regulates alcohol addiction. J Neurosci 24: 10542-10552. doi:10.1523/jneurosci.3714-04.2004

McGough NNH, Thomas JD, Dominguez HD, Riley EP. 2009. Insulin-like growth factor-I mitigates motor coordination deficits associated with neonatal alcohol exposure in rats. Neurotoxicol Teratol 31: 40-48. doi:10.1016/j .ntt.2008.08.001

Miller MW. 2004. Repeated episodic exposure to ethanol affects neurotrophin content in the forebrain of the mature rat. Exp Neurol 189: 173-181. doi:10.1016/j .expneurol.2004.05.026

Miller MW, Mooney SM. 2004. Chronic exposure to ethanol alters neurotrophin content in the basal forebrain-cortex system in the mature rat: effects on autocrine-paracrine mechanisms. J Neurobiol 60: 490-498. doi:10.1002/neu .20059

Minichiello L. 2009. TrkB signalling pathways in LTP and learning. Nat Rev Neurosci 10: 850-860. doi:10.1038/ nrn2738

Molteni R, Lipska BK, Weinberger DR, Racagni G, Riva MA. 2001a. Developmental and stress-related changes of neurotrophic factor gene expression in an animal model of 
M. Liran et al.

schizophrenia. Mol Psychiatry 6: 285-292. doi:10.1038/s .mp.4000865

Molteni R, Fumagalli F, Magnaghi V, Roceri M, Gennarelli M, Racagni G, Melcangi RC, Riva MA. 2001b. Modulation of fibroblast growth factor- 2 by stress and corticosteroids: from developmental events to adult brain plasticity. Brain Res Brain Res Rev 37: 249-258. doi:10.1016/S01650173(01)00128-X

Moonat S, Sakharkar AJ, Zhang H, Pandey SC. 2011. The role of amygdaloid brain-derived neurotrophic factor, activity-regulated cytoskeleton-associated protein and dendritic spines in anxiety and alcoholism. Addict Biol 16: 238-250. doi:10.1111/j.1369-1600.2010.00275.x

Morris SW, Naeve C, Mathew P, James PL, Kirstein MN, Cu X, Witte DP. 1997. ALK, the chromosome 2 gene locus altered by the $t(2 ; 5)$ in non-Hodgkin's lymphoma, en codes a novel neural receptor tyrosine kinase that is highly related to leukocyte tyrosine kinase (LTK). Oncogene 14: 2175-2188. doi:10.1038/sj.onc.1201062

Muramatsu T. 2011. Midkine: a promising molecule for drug development to treat diseases of the central nervous system. Curr Pharm Des 17: 410-423. doi:10.2174/ 138161211795164167

Neasta J, Ben Hamida S, Yowell QV, Carnicella S, Ron D. 2011. AKT signaling pathway in the nucleus accumbens mediates excessive alcohol drinking behaviors. Biol Psychiatry 70: 575-582. doi:10.1016/j.biopsych.2011.03.019

Neasta J, Kiely PA, He D-Y, Adams DR, O'Connor R, Ron D. 2012. Direct interaction between scaffolding proteins RACK1 and $14-3-3 \zeta$ regulates brain-derived neurotrophic factor (BDNF) transcription. J Biol Chem 287: 322-336. doi:10.1074/jbc.M111.272195

Nestler EJ. 2013. Cellular basis of memory for addiction. Dialogues Clin Neurosci 15: 431-443.

Nubukpo P, Ramoz N, Girard M, Malauzat D, Gorwood P 2017. Determinants of blood brain-derived neurotrophic factor blood levels in patients with alcohol use disorder. Alcohol Clin Exp Res 41: 1280-1287. doi:10.1111/acer .13414

Numakawa T, Yokomaku D, Kiyosue K, Adachi N, Matsumoto T, Numakawa Y, Taguchi T, Hatanaka H, Yamada M. 2002. Basic fibroblast growth factor evokes a rapid glutamate release through activation of the MAPK pathway in cultured cortical neurons. J Biol Chem 277: 2886128869. doi:10.1074/jbc.M202927200

Ortega-de San Luis C, Pascual A. 2016. Simultaneous detection of both GDNF and GFR $\alpha 1$ expression patterns in the mouse central nervous system. Front Neuroanat 10: 73 . doi:10.3389/fnana.2016.00073

Owada K, Sanjo N, Kobayashi T, Mizusawa H, Muramatsu H, Muramatsu T, Michikawa M. 1999. Midkine inhibits caspase-dependent apoptosis via the activation of mitogen-activated protein kinase and phosphatidylinositol 3 kinase in cultured neurons. J Neurochem 73: 2084-2092.

Pandey SC, Roy A, Zhang H, Xu T. 2004. Partial deletion of the cAMP response element-binding protein gene promotes alcohol-drinking behaviors. J Neurosci 24: 5022 5030. doi:10.1523/jneurosci.5557-03.2004

Pandey SC, Zhang H, Roy A, Misra K. 2006. Central and medial amygdaloid brain-derived neurotrophic factor signaling plays a critical role in alcohol-drinking and anx- iety-like behaviors. J Neurosci 26: 8320-8331. doi:10 .1523/jneurosci.4988-05.2006

Pandey SC, Zhang H, Ugale R, Prakash A, Xu T, Misra K. 2008. Effector immediate-early gene arc in the amygdala plays a critical role in alcoholism. J Neurosci 28: 25892600. doi:10.1523/jneurosci.4752-07.2008

Paratcha G, Ledda F, Baars L, Coulpier M, Besset V, Anders J, Scott R, Ibáñez CF. 2001. Released GFR $\alpha 1$ potentiates downstream signaling, neuronal survival, and differentiation via a novel mechanism of recruitment of c-Ret to lipid rafts. Neuron 29: 171-184. doi:10.1016/S0896-6273 (01)00188-X

Paratcha G, Ledda F, Ibáñez CF. 2003. The neural cell adhesion molecule NCAM is an alternative signaling receptor for GDNF family ligands. Cell 113: 867-879. doi:10.1016/ S0092-8674(03)00435-5

Park H, Poo MM. 2013. Neurotrophin regulation of neural circuit development and function. Nat Rev Neurosci 14: 7-23. doi:10.1038/nrn3379

Peltier J, O'Neill A, Schaffer DV. 2007. PI3K/Akt and CREB regulate adult neural hippocampal progenitor proliferation and differentiation. Dev Neurobiol 67: 1348-1361. doi:10.1002/dneu.20506

Perez JA, Clinton SM, Turner CA, Watson SJ, Akil H. 2009. A new role for FGF2 as an endogenous inhibitor of anxiety. J Neurosci 29: 6379-6387. doi:10.1523/jneurosci .4829-08.2009

Pochon NA-M, Menoud A, Tseng JL, Zurn AD, Aebischer P. 1997. Neuronal GDNF expression in the adult rat nervous system identified by in situ hybridization. Eur J Neurosci 9: 463-471. doi:10.1111/j.1460-9568.1997.tb01623.x

Prakash A, Zhang H, Pandey SC. 2008. Innate differences in the expression of brain-derived neurotrophic factor in the regions within the extended amygdala between alcohol preferring and nonpreferring rats. Alcohol Clin Exp Res 32: 909-920. doi:10.1111/j.1530-0277.2008.00650.x

Rehm J. 2011. The risks associated with alcohol use and alcoholism. Alcohol Res Health 34: 135-143.

Reinhardt RR, Bondy CA. 1994. Insulin-like growth factors cross the blood-brain barrier. Endocrinology 135: $1753-$ 1761. doi:10.1210/endo.135.5.7525251

Reuss B, von Bohlen und Halbach O. 2003. Fibroblast growth factors and their receptors in the central nervous system. Cell Tissue Res 313: 139-157. doi:10.1007/s00441-0030756-7

Rhodes JS, Ford MM, Yu C-H, Brown LL, Finn DA, Garland $\mathrm{T} \mathrm{Jr}$, Crabbe JC. 2007. Mouse inbred strain differences in ethanol drinking to intoxication. Genes Brain Behav 6: 118. doi:10.1111/j.1601-183X.2006.00210.x

Rios M, Fan G, Fekete C, Kelly J, Bates B, Kuehn R, Lechan RM, Jaenisch R. 2001. Conditional deletion of brain-derived neurotrophic factor in the postnatal brain leads to obesity and hyperactivity. Mol Endocrinol 15: 1748-1757. doi:10.1210/mend.15.10.0706

Riva MA, Molteni R, Bedogni F, Racagni G, Fumagalli F. 2005. Emerging role of the FGF system in psychiatric disorders. Trends Pharmacol Sci 26: 228-231. doi:10 $.1016 /$ j.tips.2005.03.001

Röjdmark S, Brismar K. 2001. Decreased IGF-I bioavailability after ethanol abuse in alcoholics: partial restitution 
after short-term abstinence. J Endocrinol Invest 24: 476482. doi:10.1007/BF03343879

Röjdmark S, Rydvald Y, Aquilonius A, Brismar K. 2000. Insulin-like growth factor (IGF)-1 and IGF-binding protein- 1 concentrations in serum of normal subjects after alcohol ingestion: evidence for decreased IGF-1 bioavailability. Clin Endocrinol (Oxf) 52: 313-318. doi:10.1046/j 1365-2265.2000.00908.x

Röjdmark S, Calissendorff J, Brismar K. 2001. Alcohol ingestion decreases both diurnal and nocturnal secretion of leptin in healthy individuals. Clin Endocrinol 55: 639647. doi:10.1046/j.1365-2265.2001.01401.x

Ron D, Barak S. 2016. Molecular mechanisms underlying alcohol-drinking behaviours. Nat Rev Neurosci 17: 576591. doi:10.1038/nrn.2016.85

Ron D, Berger A. 2018. Targeting the intracellular signaling "STOP" and "GO" pathways for the treatment of alcohol use disorders. Psychopharmacology (Berl) 235: 17271743. doi:10.1007/s00213-018-4882-z

Sadri-Vakili G, Kumaresan V, Schmidt HD, Famous KR, Chawla P, Vassoler FM, Overland RP, Xia E, Bass CE, Terwilliger EF, et al. 2010. Cocaine-induced chromatin remodeling increases brain-derived neurotrophic factor transcription in the rat medial prefrontal cortex, which alters the reinforcing efficacy of cocaine. J Neurosci 30: 11735-11744. doi:10.1523/jneurosci.2328-10.2010

Sariola H, Saarma M. 2003. Novel functions and signalling pathways for GDNF. J Cell Sci 116: 3855-3862. doi:10 $.1242 /$ jcs. 00786

Schweitzer P, Cates-Gatto C, Varodayan FP, Nadav T, Roberto M, Lasek AW, Roberts AJ. 2016. Dependence-induced ethanol drinking and GABA neurotransmission are altered in Alk deficient mice. Neuropharmacology 107: 1-8. doi:10.1016/j.neuropharm.2016.03.003

Sharma S, Graham R, Rohde R, Ceballos NA. 2017. Stressinduced change in serum BDNF is related to quantitative family history of alcohol use disorder and age at first alcohol use. Pharmacol Biochem Behav 153: 12-17. doi:10.1016/j.pbb.2016.12.002

Shen R-Y. 2003. Ethanol withdrawal reduces the number of spontaneously active ventral tegmental area dopamine neurons in conscious animals. J Pharmacol Exp Ther 307: 566-572. doi:10.1124/jpet.103.053371

Shen R-Y, Choong K-C, Thompson AC. 2007. Long-term reduction in ventral tegmental area dopamine neuron population activity following repeated stimulant or ethanol treatment. Biol Psychiatry 61: 93-100. doi:10.1016/j .biopsych.2006.03.018

Singh SP, Ehmann S, Snyder AK. 1996. Ethanol-induced changes in insulin-like growth factors and IGF gene expression in the fetal brain. Proc Soc Exp Biol Med 212: 349-354. doi:10.3181/00379727-212-44025

Solomon MG, Griffin WC, Lopez MF, Becker HC. 2019. Brain regional and temporal changes in BDNF mRNA and microRNA-206 expression in mice exposed to repeated cycles of chronic intermittent ethanol and forced swim stress. Neuroscience 406: 617-625. doi:10.1016/j .neuroscience.2019.02.012

Soscia SJ, Tong M, Xu XJ, Cohen AC, Chu J, Wands JR, de la Monte SM. 2006. Chronic gestational exposure to ethanol causes insulin and IGF resistance and impairs acetylcho- line homeostasis in the brain. Cell Mol Life Sci 63: 20392056. doi:10.1007/s00018-006-6208-2

Stragier E, Massart R, Salery M, Hamon M, Geny D, Martin V, Boulle F, Lanfumey L. 2015. Ethanol-induced epigenetic regulations at the $B d n f$ gene in $\mathrm{C} 57 \mathrm{BL} / 6 \mathrm{~J}$ mice. Mol Psychiatry 20: 405-412. doi:10.1038/mp.2014.38

Sun W-L, Zelek-Molik A, McGinty JF. 2013. Short and long access to cocaine self-administration activates tyrosine phosphatase STEP and attenuates GluN expression but differentially regulates GluA expression in the prefrontal cortex. Psychopharmacology (Berl) 229: 603-613. doi:10 .1007/s00213-013-3118-5

Tansey MG, Baloh RH, Milbrandt J, Johnson EM Jr. 2000. GFR $\alpha$-mediated localization of RET to lipid rafts is required for effective downstream signaling, differentiation, and neuronal survival. Neuron 25: 611-623. doi:10.1016/ S0896-6273(00)81064-8

Tapia-Arancibia L, Rage F, Givalois L, Dingeon P, Arancibia S, Beauge F. 2001. Effects of alcohol on brain-derived neurotrophic factor mRNA expression in discrete regions of the rat hippocampus and hypothalamus. J Neurosci Res 63: 200-208. doi:10.1002/1097-4547(20010115)63:2<200 ::AID-JNR1012>3.0.CO;2-Q

Tapocik JD, Barbier E, Flanigan M, Solomon M, Pincus A, Pilling A, Sun H, Schank JR, King C, Heilig M. 2014. microRNA-206 in rat medial prefrontal cortex regulates BDNF expression and alcohol drinking. $J$ Neurosci 34: 4581-4588. doi:10.1523/jneurosci.0445-14.2014

Timmer M, Cesnulevicius K, Winkler C, Kolb J, LipokaticTakacs E, Jungnickel J, Grothe C. 2007. Fibroblast growth factor (FGF)-2 and FGF receptor 3 are required for the development of the substantia nigra, and FGF-2 plays a crucial role for the rescue of dopaminergic neurons after 6-hydroxydopamine lesion. J Neurosci 27: 459-471. doi:10.1523/jneurosci.4493-06.2007

Tomac A, Widenfalk J, Lin LF, Kohno T, Ebendal T, Hoffer BJ, Olson L. 1995. Retrograde axonal transport of glial cell line-derived neurotrophic factor in the adult nigrostriatal system suggests a trophic role in the adult. Proc Natl Acad Sci 92: 8274-8278. doi:10.1073/pnas.92.18.8274

Trupp M, Belluardo N, Funakoshi H, Ibáñez CF. 1997. Complementary and overlapping expression of glial cell line-derived neurotrophic factor (GDNF), c-ret protooncogene, and GDNF receptor- $\alpha$ indicates multiple mechanisms of trophic actions in the adult rat CNS. $J$ Neurosci 17: 3554-3567. doi:10.1523/jneurosci.17-1003554.1997

Tsui CC, Gabreski NA, Hein SJ, Pierchala BA. 2015. Lipid rafts are physiologic membrane microdomains necessary for the morphogenic and developmental functions of glial cell line-derived neurotrophic factor in vivo. J Neurosci 35: 13233-13243. doi:10.1523/jneurosci.293514.2015

Turner CA, Watson SJ, Akil H. 2012. The fibroblast growth factor family: neuromodulation of affective behavior. Neuron 76: 160-174. doi:10.1016/j.neuron.2012.08.037

van Scheltinga AFT, Bakker SC, Kahn RS. 2010. Fibroblast growth factors in schizophrenia. Schizophr Bull 36: 11571166. doi:10.1093/schbul/sbp033

Vargas-Perez H, Ting-A-Kee R, Walton CH, Hansen DM, Razavi R, Clarke L, Bufalino MR, Allison DW, Steffensen SC, van der Kooy D. 2009. Ventral tegmental area BDNF 
M. Liran et al.

induces an opiate-dependent-like reward state in naive rats. Science 324: 1732-1734. doi:10.1126/science.116 8501

Vicente-Rodríguez M, Pérez-García C, Haro M, Ramos MP, Herradón G. 2014a. Genetic inactivation of midkine modulates behavioural responses to ethanol possibly by enhancing $\mathrm{GABA}_{\mathrm{A}}$ receptor sensitivity to $\mathrm{GABA}_{\mathrm{A}}$ acting drugs. Behav Brain Res 274: 258-263. doi:10.1016/j.bbr .2014 .08 .023

Vicente-Rodríguez M, Pérez-García C, Ferrer-Alcón M, Uribarri M, Sánchez-Alonso MG, Ramos MP, Herradón G. 2014b. Pleiotrophin differentially regulates the rewarding and sedative effects of ethanol. J Neurochem 131: 688695. doi:10.1111/jnc.12841

Volkow ND, Morales M. 2015. The brain on drugs: from reward to addiction. Cell 162: 712-725. doi:10.1016/j cell.2015.07.046

Wan L, Xie Y, Su L, Liu Y, Wang Y, Wang Z. 2011. RACK1 affects morphine reward via BDNF. Brain Res 1416: 2634. doi:10.1016/j.brainres.2011.07.045

Wang J, Carnicella S, Ahmadiantehrani S, He D-Y, Barak S, Kharazia V, Ben Hamida S, Zapata A, Shippenberg TS, Ron D. 2010. Nucleus accumbens-derived glial cell linederived neurotrophic factor is a retrograde enhancer of dopaminergic tone in the mesocorticolimbic system. J Neurosci 30: 14502-14512. doi:10.1523/jneurosci.39 09-10.2010

Warnault V, Darcq E, Morisot N, Phamluong K, Wilbrecht L, Massa SM, Longo FM, Ron D. 2016. The BDNF valine 68 to methionine polymorphism increases compulsive alcohol drinking in mice that is reversed by tropomyosin receptor kinase B activation. Biol Psychiatry 79: 463-473. doi:10.1016/j.biopsych.2015.06.007

Weiss F, Parsons LH, Schulteis G, Hyytiä P, Lorang MT, Bloom FE, Koob GF. 1996. Ethanol self-administration restores withdrawal-associated deficiencies in accumbal dopamine and 5-hydroxytryptamine release in dependent rats. J Neurosci 16: 3474-3485. doi:10.1523/jneuro sci.16-10-03474.1996

Wellstein A. 2012. ALK receptor activation, ligands and therapeutic targeting in glioblastoma and in other cancers. Front Oncol 2: 192. doi:10.3389/fonc.2012.00192

Werner H, LeRoith D. 2014. Insulin and insulin-like growth factor receptors in the brain: physiological and pathological aspects. Eur Neuropsychopharmacol 24: 1947-1953. doi:10.1016/j.euroneuro.2014.01.020

Whiteford HA, Degenhardt L, Rehm J, Baxter AJ, Ferrari AJ, Erskine HE, Charlson FJ, Norman RE, Flaxman AD, Johns N, et al. 2013. Global burden of disease attributable to mental and substance use disorders: findings from the Global Burden of Disease Study 2010. Lancet 382: 15751586. doi:10.1016/S0140-6736(13)61611-6

Whitfield TW Jr, Shi X, Sun W-L, McGinty JF. 2011. The suppressive effect of an intra-prefrontal cortical infusion of BDNF on cocaine-seeking is Trk receptor and extracellular signal-regulated protein kinase mitogen-activated protein kinase dependent. J Neurosci 31: 834-842. doi:10 .1523/jneurosci.4986-10.2011

Wise RA. 2009. Roles for nigrostriatal-not just mesocorticolimbic-dopamine in reward and addiction. Trends Neurosci 32: 517-524. doi:10.1016/j.tins.2009.06.004

Wojnar M, Brower KJ, Strobbe S, Ilgen M, Matsumoto H, Nowosad I, Sliwerska E, Burmeister M. 2009. Association between Val66Met brain-derived neurotrophic factor (BDNF) gene polymorphism and post-treatment relapse in alcohol dependence. Alcohol Clin Exp Res 33: 693-702. doi:10.1111/j.1530-0277.2008.00886.x

World Health Organization. 2014. Global status report on alcohol and health 2014. WHO, Geneva, Switzerland.

World Health Organization. 2018. Global status report on alcohol and health 2018. WHO, Geneva, Switzerland.

Wrigley S, Arafa D, Tropea D. 2017. Insulin-like growth factor 1: at the crossroads of brain development and aging. Front Cell Neurosci 11: 14. doi:10.3389/fncel.2017.00014

Xia L, Zhai M, Wang L, Miao D, Zhu X, Wang W. 2013. FGF2 blocks PTSD symptoms via an astrocyte-based mechanism. Behavioural Brain Res 256: 472-480. doi:10 .1016/j.bbr.2013.08.048

Yaka R, He D-Y, Phamluong K, Ron D. 2003. Pituitary adenylate cyclase-activating polypeptide (PACAP $(1-38)$ ) enhances $\mathrm{N}$-methyl-D-aspartate receptor function and brain-derived neurotrophic factor expression via RACK1. J Biol Chem 278: 9630-9638. doi:10.1074/jbc .M209141200

Yan Q-S, Feng M-J, Yan S-E. 2005. Different expression of brain-derived neurotrophic factor in the nucleus accumbens of alcohol-preferring (P) and -nonpreferring (NP) rats. Brain Res 1035: 215-218. doi:10.1016/j.brainres .2004 .12 .039

Yang F, Feng L, Zheng F, Johnson SW, Du J, Shen L, Wu CP, Lu B. 2001. GDNF acutely modulates excitability and Atype $\mathrm{K}^{+}$channels in midbrain dopaminergic neurons. Nat Neurosci 4: 1071-1078. doi:10.1038/nn734

You C, Zhang H, Sakharkar AJ, Teppen T, Pandey SC. 2014. Reversal of deficits in dendritic spines, BDNF and Arc expression in the amygdala during alcohol dependence by HDAC inhibitor treatment. Int J Neuropsychopharmacol 17: 313-322. doi:10.1017/S1461145713001144

Zagrebelsky M, Korte M. 2014. Form follows function: BDNF and its involvement in sculpting the function and structure of synapses. Neuropharmacology 76: 628638. doi:10.1016/j.neuropharm.2013.05.029

Zanardini R, Fontana A, Pagano R, Mazzaro E, Bergamasco F, Romagnosi G, Gennarelli M, Bocchio-Chiavetto L. 2011. Alterations of brain-derived neurotrophic factor serum levels in patients with alcohol dependence. Alcohol Clin Exp Res 35: 1529-1533.

Zipori D, Sadot-Sogrin Y, Goltseker K, Even-Chen O, Rahamim N, Shaham O, Barak S. 2017. Re-exposure to nicotine-associated context from adolescence enhances alcohol intake in adulthood. Sci Rep 7: 2479. doi:10.1038/ s41598-017-02177-2 


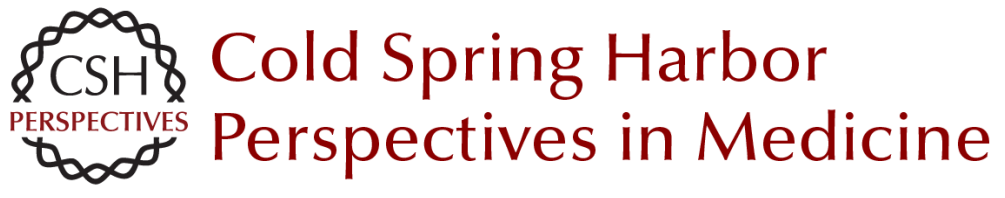

\section{Growth Factors and Alcohol Use Disorder}

Mirit Liran, Nofar Rahamim, Dorit Ron and Segev Barak

Cold Spring Harb Perspect Med 2020; doi: 10.1101/cshperspect.a039271 originally published online January 21, 2020

\section{Subject Collection Addiction}

Developments from Bulk Optogenetics to Single-Cell Strategies to Dissect the Neural Circuits that Underlie Aberrant Motivational States Jose Rodriguez-Romaguera, Vijay M.K. Namboodiri, Marcus L. Basiri, et al.

Consequences of Parental Opioid Exposure on Neurophysiology, Behavior, and Health in the Next Generations

Fair M. Vassoler and Mathieu E. Wimmer

Animal Models of the Behavioral Symptoms of Substance Use Disorders Louk J.M.J. Vanderschuren and Serge H. Ahmed

Translational Research in Nicotine Addiction Miranda L. Fisher, James R. Pauly, Brett Froeliger, et al.

Neonatal Opioid Withdrawal Syndrome (NOWS): A Transgenerational Echo of the Opioid Crisis Andrew E. Weller, Richard C. Crist, Benjamin C. Reiner, et al.

Impairment of Synaptic Plasticity by Cannabis, $\Delta^{\mathbf{9}}$ -THC, and Synthetic Cannabinoids Alexander F. Hoffman, Eun-Kyung Hwang and Carl R. Lupica

Drug-Evoked Synaptic Plasticity of Excitatory Transmission in the Ventral Tegmental Area Camilla Bellone, Michael Loureiro and Christian Lüscher

Opioid-Induced Molecular and Cellular Plasticity of Ventral Tegmental Area Dopamine Neurons Marie A. Doyle and Michelle S. Mazei-Robison
The Persistent Challenge of Developing Addiction Pharmacotherapies

Sarah E. Swinford-Jackson, Charles P. O'Brien,

Paul J. Kenny, et al.

Opioid Modulation of the Gut-Brain Axis in Opioid-Associated Comorbidities

Li Zhang and Sabita Roy

Epigenetics of Drug Addiction Andrew F. Stewart, Sasha L. Fulton and lan Maze

Genetic Vulnerability to Opioid Addiction Brian Reed and Mary Jeanne Kreek

Glutamatergic Systems and Memory Mechanisms

Underlying Opioid Addiction Jasper A. Heinsbroek, Taco J. De Vries and Jamie Peters

Mechanisms of Nicotine Addiction Marina R. Picciotto and Paul J. Kenny

Neural Substrates and Circuits of Drug Addiction Matthew W. Feltenstein, Ronald E. See and Rita A. Fuchs

The Role of the Central Amygdala in Alcohol Dependence Marisa Roberto, Dean Kirson and Sophia Khom

For additional articles in this collection, see http://perspectivesinmedicine.cshlp.org/cgi/collection/ 